\title{
SUPERVISION OF THE RESPONSIBLE LENDING REGIMES: THEORY, EVIDENCE, ANALYSIS AND REFORMS*
}

\author{
Gill North $^{* *}$ and Therese Wilson ${ }^{* * *}$
}

\begin{abstract}
National responsible lending regimes have operated in Australia since 2009, with the stated aims to encourage prudent lending, curtail undesirable market practices, and impose sanctions for irresponsible lending and leasing. This article outlines a study of the supervision of the responsible lending rules by the Australian Securities and Investments Commission (ASIC) from 2014 to mid-2017. The study finds that the Commission proactively engaged with lenders, encouraged tighter lending standards, and sought or imposed severe penalties for egregious conduct. Further, the Commission strategically targeted credit products commonly acknowledged as the riskiest or most material from a borrower's perspective, such as small amount credit contracts, interest only home loans, and car loans. Despite these positive findings, however, many households are heavily indebted and large segments of the community and the nation are highly susceptible to future harm. In this environment, we question the timeliness and sufficiency of the Commission's interventions and responses, and predict further litigation that tests the boundaries of the responsible lending rules. Moving forward, we call for more systematic supervision of responsible lending risks, practices and exposures and propose modest reforms that require lenders to better inform and engage with consumers about the risks of elevated levels of debt.
\end{abstract}

\section{INTRODUCTION}

Australia is a fortunate country in many ways and has benefited greatly from a period of economic prosperity lasting more than 25 years. ${ }^{1}$ Much of this prosperity has been funded by credit, with loan growth over this period well above levels of economic

Readers should note that this article was accepted for publication in February 2018, prior to the start of the Royal Commission into Misconduct in the Banking, Superannuation and Financial Services Industry.

** Professorial Research Fellow, Law School, Deakin University; Adjunct Associate Professor, Law School, University of Western Australia.

*** Associate Professor, Law School, Griffith University.

1 Digital Finance Analytics and the Centre for Commercial Law and Regulatory Studies at Monash University, 'The Stressed Finance Landscape Data Analysis' (Report, October 2015) Ben Phillips and Matthew Taylor, 'Buy Now and Pay Later: Household Debt in Australia' (Income and Wealth Report Issue 38, AMP.NATSEM, December 2015) 6. 
activity. ${ }^{2}$ The provision of credit to households is a two-edged sword though. When used appropriately, credit can assist consumers to purchase goods and services or to leverage the acquisition of assets for investment purposes. However, as the amount of outstanding consumer credit continues to expand, concerns around the exposure of the lending institutions, and more especially their borrowers, are intensifying. ${ }^{3}$ Issues concerning responsible lending ultimately compound at a household level, ${ }^{4}$ with household debt to disposable income now at record levels. ${ }^{5}$ As debt levels grow, households can find themselves in a position of increasing financial stress and can fall into a debt spiral if they do not act quickly to regain control of their finances. In extreme cases where debt is not managed appropriately, borrowers can end up in a position of financial exclusion 6 or bankruptcy, ${ }^{7}$ and can lose their personal assets, including the family home and car. Given these significant risks, consumers of credit are afforded protections under the National Consumer Credit Protection Act 2009 (Cth) (NCCP).

The NCCP includes, among its consumer credit protections, responsible lending regimes that apply to all credit providers in Australia. ${ }^{8}$ These regimes impose an obligation on credit providers and credit assistance providers to ensure a loan is suitable for the borrower (or more precisely, that it is not unsuitable).${ }^{9}$ The key factor that these

2 Reserve Bank of Australia (RBA), Chart Pack (August 2017) 9. See also Gill North, 'Small Amount Credit Contract Reforms in Australia: Household Survey Evidence and Analysis' (2016) 27 Journal of Banking and Finance Law and Practice 203, 208.

3 See Philip Lowe, 'Household Debt, Housing Prices and Resilience' (Speech delivered at Economic Society of Australia (QLD) Business Lunch, Brisbane, 4 May 2017); Gill North, 'The Australian House Party has been Glorious - But the Hangover May Be Severe: Reforms to Mitigate Some of the Risks' in Ron Levy et al (eds), New Directions for Law in Australia: Essays in Contemporary Law Reform (ANU Press, 2017).

4 North, 'Small Amount Credit Contract Reforms in Australia', above n 2, 203.

5 Ibid 203; RBA, Statistical Tables: E2 Household Finances-Selected Ratios (21 December 2017).

6 See Commonwealth, Strategies for Reducing Reliance on High-cost, Short-term, Small Amount Lending, Discussion Paper (April 2012) 3-4. See also Chris Connolly, Measuring Financial Exclusion in Australia (Report, Centre for Social Impact, University of New South Wales, 2014) 5, 9; Kristy Muir, Axelle Marjolin and Sarah Adams, Eight Years on the Fringe: What Has It Meant To Be Severely or Fully Financially Excluded in Australia? (Report, Centre for Social Impact, University of New South Wales, 2015) 5.

7 Bankruptcy Act 1966 (Cth). See Australian Financial Security Authority, Non-Business Related Causes of Personal Insolvencies 2016-17 <https://www.afsa.gov.au/statistics/causes-nonbusiness-related $>$. These statistics show that excessive use of credit is now the most common non-business related cause of personal insolvencies in Australia. See also Paul Ali et al, 'The Incidence and Causes of Personal Bankruptcy in Australia' (2016) 4 JASSA - Finsia Journal of Applied Finance 27.

8 The responsible lending provisions are a sub-set of the various laws designed to protect consumers of credit.

9 National Consumer Credit Protection Act 2009 (Cth) ('NCCP') pts 3.1-3.2. Section 8 of the NCCP states that a person provides credit assistance to a consumer if, by dealing directly with the consumer or the consumer's agent in the course of, as part of, or incidentally to, a business carried on in this jurisdiction by the person or another person, the person: (a) suggests that the consumer apply for a particular credit contract with a particular credit provider; or (b) suggests that the consumer apply for an increase to the credit limit of a particular credit contract with a particular credit provider; or (c) suggests that the consumer remain in a particular credit contract with a particular credit provider; or (d) assists the consumer to 
credit licensees must consider when determining whether a loan is suitable is the ability of the borrower to repay the loan. This suitability assessment must be verified by gathering information that confirms the financial capacity of the consumer to meet the relevant loan commitments. ${ }^{10}$ Lenders must also document the purposes of a loan because the proposed credit must satisfy the objectives and requirements of the borrower. ${ }^{11}$ ASIC is required to supervise and enforce these provisions. ${ }^{12}$ The stated aims of the responsible lending rules are to encourage prudent lending and introduce appropriate standards of conduct, ${ }^{13}$ to curtail undesirable market practices, ${ }^{14}$ and to impose sanctions for irresponsible lending and leasing. ${ }^{15}$ These principles are acknowledged internationally and supervisory bodies confirm the importance of robust national frameworks governing responsible lending, especially to consumers. ${ }^{16}$

Active monitoring and enforcement of the responsible lending regimes in Australia is essential to address issues arising from irresponsible lending, consumer overindebtedness, and financial stability concerns, but extant literature on this critical area of law is scarce. Accordingly, this article outlines a study that examines and critiques the supervision of the responsible lending rules by ASIC from the beginning of 2014 to the end of June 2017, including enforcement actions, relevant legal theory, and the longerterm effects. The aim of the study is to provide a nuanced picture of the theory, law and practice of responsible lending in Australia, with an intentional focus on the current and prospective risks and exposures of borrowers (rather than the status of lending entities).

A search of ASIC's website revealed 93 actions initiated by ASIC in response to alleged breaches of the responsible lending provisions. Nearly 90 per cent of those actions involved small amount credit contracts (SACCs), car loans, and standard home loans, ${ }^{17}$ with the remaining actions concerning overdraft facilities and credit cards. To

apply for a particular credit contract with a particular credit provider; or (e) assists the consumer to apply for an increase to the credit limit of a particular credit contract with a particular credit provider; or (f) suggests that the consumer apply for a particular consumer lease with a particular lessor; or (g) suggests that the consumer remain in a particular consumer lease with a particular lessor; or $(\mathrm{h})$ assists the consumer to apply for a particular consumer lease with a particular lessor.

10 NCCP ss 115-16, 128-32.

11 Ibid.

12 The Australian Prudential Regulation Authority (APRA) is responsible for the prudential supervision of authorised deposit institutions in Australia. The actions taken by APRA around lending standards are reviewed in a companion article because the roles and responsibilities of the Australian Securities and Investments Commission (ASIC) and APRA differ markedly. See Gill North and Therese Wilson, 'Prudential Supervision of Residential Property Lending: Has APRA Been Asleep at the Wheel?' (Working Paper, May 2018).

13 Explanatory Memorandum, National Consumer Credit Protection Bill 2009 (Cth) [3.16].

14 Ibid [3.11].

15 Ibid [3.16].

16 See, eg, James Eyers, 'APRA to Ramp Up Scrutiny of Bank Lending Practices', The Australian Financial Review (online), 8 September $2017<$ http://www.afr.com/x/gydmfb>; Bank of England, 'Financial Stability Report' (Report No 42, Bank of England, November 2017) 1320.

17 For the purposes of this article, the term 'standard home loan' includes mortgages on residential properties for the purposes of owner occupation and or investment but excludes reverse mortgages. Reverse mortgages are a specialised and complex form of loan and represent only a tiny share of outstanding residential property loans in Australia. 
keep the article to a manageable scope, the subsequent legal outlines and analysis centre on the credit products that feature most prominently in the study. A focus on these credit segments (by ASIC and ourselves) is appropriate. First, the magnitude and impact of standard home loans on household debt and national outcomes in Australia is difficult to overstate. ${ }^{18}$ Secondly, SACCs and car loans are often sought as last resort credit by consumers from the most disadvantaged and vulnerable communities in Australia, so the need for responsible lending to these consumers is acute. ${ }^{19}$ Finally, growth in outstanding SACCs and car loans in Australia appears to be well above economic activity levels and other forms of credit, and accelerating. ${ }^{20}$

Our study finds that ASIC conducted reviews of the responsible lending standards of these three credit segments and used the evidence it gleaned to initiate actions against a range of credit providers. When doing so, ASIC used its full arsenal of powers, including proactive engagement and enforcement approaches ranging from low level interventions to more severe forms of punishment. These layered regulatory responses were consistent with the enforcement pyramid theory developed by Ayres and Braithwaite in the early 1990s. This theory suggests that for regulation to be effective, supervisors need enforcement options on a tiered basis, to enable them to respond to industry participants using light touch options, while retaining the threat of more severe action. ${ }^{21}$ ASIC's strategic enforcement approach also reflects a positive shift from earlier criticisms that it had generally behaved in a reactive rather than proactive fashion. ${ }^{22} \mathrm{At}$

18 The monthly data from the Reserve Bank of Australia indicates that mortgage loans totalled more than $\$ 1,723$ billion at the end of December 2017 and represented nearly 62 per cent of total credit on a seasonally adjusted basis: Reserve Bank of Australia Monthly Data December - D2 Lending and credit aggregates (Released 31 Jan 2018)

19 See North, 'Small Amount Credit Contract Reforms in Australia', above n 2

20 Ibid 208; Martin North, 'Pay Day Lending Running Hot' (30 January 2018) Digital Finance Analytics <http://digitalfinanceanalytics.com/blog/pay-day-lending-still-running-hot/>; Jill Treanor, 'UK Financial Watchdog Investigates Car Loans Market', The Guardian (online), 29 June 2017 <https://www.theguardian.com/business/2017/jun/29/uk-fca-car-loansmarket>.

The North article finds that SACC loans increased an estimated 10 per cent per annum from 2005 to 2015 . Over the same period, total credit rose 7 per cent per annum, with mortgages (including owner occupied and investor loans) rising 7.8 per cent; other personal credit 2.2 perc ent; and business credit 5.8 per cent.

More recent RBA data indicates that the growth levels of credit for 2016 and 2017 were as follows: housing (6.3 per cent in both years), personal loans ( -0.9 and -1.1 per cent); business loans (5.3 and 3.2 per cent) and total credit (5.6 and 4.8 per cent). The RBA data excludes SACCs, but household survey data collected by Digital Finance Analytics suggests growth in SACC loans was 10.7 per cent and 14.5 per cent in 2016 and 2017 respectively.

In contrast, total consumer credit is rising in the United Kingdom (UK) at 10.3 per cent a year, with growth in the car finance segment most rapid at 15 per cent per annum. The Bank of England and Financial Conduct Authority are concerned about the lack of transparency, potential conflicts of interest, and possible irresponsible lending in car financing. While specific data on car loans is not collected or published in Australia, the trends and issues highlighted in the UK may apply in Australia.

21 Ian Ayres and John Braithwaite, Responsive Regulation: Transcending the Deregulation Debate (Oxford University Press, 1992) 25.

22 Vicky Comino, 'Towards Better Corporate Regulation in Australia' (2011) 26 Australian Journal of Corporate Law 6, 36. 
the same time, evidence on the financial position of Australian households raises substantive concerns regarding the consumer lending standards applied by lenders and the corresponding levels and distribution of consumer indebtedness. Further litigation by ASIC and consumers that tests the limits of the responsible lending regimes seems inevitable. When this occurs, the efficacy of the responsible lending rules and ASIC's supervision of these regimes are likely to be scrutinised by scholars and other commentators.

Our study analysis concludes that ASIC's engagements around responsible lending standards should have been timelier and more comprehensive, particularly with respect to the home loan sector. Views can reasonably differ concerning where responsibilities for credit decisions ought to lie. However, proactive steps by ASIC to protect consumers from harm arising from irresponsible lending are essential, given the significant market failures in consumer credit markets, such as imbalances of power, risk and information and consumer behavioural biases, as well as the vulnerabilities of many Australian borrowers. ${ }^{23}$ We call for more regular and systematic supervision and enforcement of responsible lending by ASIC in the future. Further, we propose reforms to the responsible lending models that require lenders to better inform and engage with households concerning the risks of excessive debt.

The article is arranged in six Parts. Part II sets the scene for the empirical study by summarising the rationales for the responsible lending regimes in Australia and relevant legal theory. Part III provides our empirical study on the supervision and enforcement of the responsible lending regimes by ASIC. Part IV outlines the responsible lending regimes and closely related legal obligations. Part V reflects on the study findings, considers alignment with accepted principles from legal theory and the regulatory performance of $\mathrm{ASIC}^{24}$ and proposes modest reforms to the responsible lending model. Part VI concludes.

\section{RESPONSIBLE LENDING REGIMES: RATIONALES AND LEGAL THEORY}

\section{A Rationales Supporting the Responsible Lending Regimes in Australia}

As previously outlined, the objectives of the responsible lending rules in Australia are to encourage prudent lending and introduce appropriate standards of conduct, curtail undesirable market practices, and impose sanctions for irresponsible lending and leasing. These goals are acknowledged internationally. The extreme and potentially devastating consequences of boom and bust credit cycles are well documented, including the proclivities of lenders to expand the provision of credit to drive activity and profits and the corresponding temptation to reduce lending standards. ${ }^{25}$ The

23 As discussed in Part V of the article, borrower vulnerabilities arise from limited income, education, and financial capacity as well as behavioural biases.

24 Commonwealth of Australia, 'Performance of the Australian Securities and Investments Commission' (Final Report, Senate Economics References Committee, 26 June 2014) [4.1][4.46].

25 See, eg, Hyman P Minsky, 'A Theory of Systemic Fragility' in Edward I Altman and Arnold W Sametz (eds), Financial Crises: Institutions and Markets in a Fragile Environment (John Wiley and Sons, 1977); Hyman P Minsky and Mark D Vaughan, 'Debt and Business Cycles' (1990) 25 Business Economics. See also Christopher Crowe et al (eds), Macrofinancial Linkages: Trends, Crises, and Policies (International Monetary Fund, 2010); The Joint Forum, 'Developments in 
Financial Stability Board confirms that 'a robust and effective assessment of individual affordability has to underpin any sustainable lending model' ${ }^{26}$ The responsible lending regulation in Australia is centred around this essential principle, as outlined in Part IV of the article.

\section{B Relevant Legal Theory and Models}

Responsible lending legal theory falls within the consumer finance literature. Much of this scholarship highlights the significant failures that arise in consumer finance markets, particularly when services are provided to the most vulnerable and disadvantaged sections of the community. 27 Many commentators highlight the limitations of disclosure policy. ${ }^{28}$ For example, Howells notes that ' [i]nformation is only useful if it can be acted upon. The poor may rationally decide not to make use of information, if they feel no alternatives will be available to them' ${ }^{29}$ The behavioural biases of consumers when dealing with financial matters is another area receiving increasing attention. One of the most critical biases of borrowers is optimism and a tendency to underestimate the likelihood of future adverse events and financial hardship. ${ }^{30}$ Hence Bar-Gill and others conclude that lenders are often in a better position than consumers to objectively assess the affordability of credit and the risks involved. ${ }^{31}$ We argue in the study analysis in Part V of this article that the responsible lending regulation in Australia should reflect, and respond to, these various consumer credit market failures.

Enforcement of the responsible lending regimes can be viewed through the prism of regulatory enforcement models. Of these models, the enforcement pyramid theory

Credit Risk Management Across Sectors: Current Practices and Recommendations' (Bank for International Settlements, June 2015).

26 Financial Stability Board, 'FSB Principles for Sound Residential Mortgage Underwriting Practices' (April 2012) 1.

27 See, eg, Iain Ramsay, 'Consumer Credit Law, Distributive Justice and the Welfare State' (1995) 15 Oxford Journal of Legal Studies 177; Paul Ali, Evgenia Bourova and Ian Ramsay, 'The Statutory Right to Seek a Credit Contract Variation on the Grounds of Hardship: A History and Analysis' (2016) 44 (1) Federal Law Review 77, 81, 101. See also Udo Reifner et al, 'Consumer Overindebtedness and Consumer Law in the European Union' (Final Report, Institute for Financial Services e.V. Erasmus University Rotterdam/School of Law University of Helsinki/Helsinki Collegium for Advanced Studies, September 2003).

28 See, eg, Alan Schwartz, 'Unconscionability and Imperfect Information: A Research Agenda' (1991) 19 Canadian Business Law Journal 437, 444-9; Therese Wilson, 'The Responsible Lending Response' in Therese Wilson (ed) International Responses to Issues of Credit and Overindebtedness in the Wake of Crisis (Ashgate, 2013) 109.

29 Geraint Howells, 'The Potential and Limits of Consumer Empowerment by Information' (2005) 32 Journal of Law and Society 349, 358.

30 See, eg, Neil D Weinstein, 'Unrealistic Optimism About Future Life Events' (1980) 39 Journal of Personality and Society Psychology 806; Cass R Sunstein, Christine Jolls and Richard H Thaler, 'A Behavioural Approach to Law and Economics' (1998) 50 Stanford Law Review 1471; Oren Bar-Gill, 'Seduction by Plastic' (2004) 98 North Western University Law Review 1373, 1396-9; David Laibson, 'Golden Eggs and Hyperbolic Discounting' (1997) 112(2) Quarterly Journal of Economics 443; John A E Pottow, 'Private Liability for Reckless Consumer Lending' (2007) 1 University of Illinois Law Review 405, 412-13. See also discussion in Iain Ramsay, Consumer Law and Policy: Text and Materials on Regulating Consumer Markets (Hart Publishing, 2007) 73, 79_ 80 .

31 See, eg, Bar-Gill, above n 30, 1375; Pottow, above n 30, 431. 
developed by Ayres and Braithwaite in the early 1990s remains seminal. This theory contends that regulators should have the capacity to, and should, respond to industry participants using a hierarchy of regulatory strategies that encompass low level proactive approaches (such as persuasion) as well as highly intrusive responses (such as court proceedings). ${ }^{32}$ More specifically, this regulatory model suggests that for regulation to be responsive and effective, it is necessary for a regulator to have a range of enforcement powers available to it, including light touch and more severe options, because without the possibility of punishment, persuasion is likely to be less effective, and without the availability of persuasion, the regime is likely to be viewed as unduly punitive. The combination of proactive measures and the possibility of serious punishment gives effect to a principle of 'minimal sufficiency' and allows a regulator to signal to participants that it will initially consider less intrusive strategies and will only escalate up the tiers of the pyramid to more severe forms of enforcement when these lower ranked responses are inappropriate or ineffective. ${ }^{33}$ As outlined in the study analysis in Part V, we find that ASIC's enforcement of the responsible lending regimes was broadly consistent with the Ayres and Braithwaite pyramid model.

\section{RESPONSIBLE LENDING REGIMES: EMPIRICAL STUDY OF ASIC'S SUPERVISION AND ENFORCEMENT}

\section{A What Motivated Our Study?}

The continuing trend of consumer credit growth in Australia well above the levels of inflation and wages growth cannot continue indefinitely. Average household debt to total disposable income is at a record level of 199.7 per cent ${ }^{34}$ and more than 32 per cent of households are in financial stress. ${ }^{35}$ The extended period of consumer credit growth and the present high levels of household indebtedness and financial stress will have serious repercussions for credit providers and borrowers in years (or decades) to come. As Philip Lowe, the Governor of the Reserve Bank of Australia, has confirmed, the 'recent increase in household debt relative to our incomes has made the economy less resilient to future shocks'. ${ }^{36}$ A significant deterioration in the financial or economic positions of Australia may lead to a cascading series of events that restricts the provision of credit and discretionary consumer spending for a long period. ${ }^{37}$ For some households, even small increases in the loan interest rates, a decline in real estate values, or a reduction in working hours or conditions may have grave consequences. Yet broader and more significant risks for borrowers include unemployment, the removal of

32 Ayres and Braithwaite, above $\mathrm{n} 21$.

33 Dimity Kingsford Smith, 'A Harder Nut to Crack? Responsive Regulation in the Financial Services Sector' (2011) 44 University of British Columbia Law Review 695, 711.

34 RBA, Statistical Tables: E2 Household Finances - Selected Ratios (21 December 2017).

35 Digital Finance Analytics proprietary data as at end of April 2018. Financial stress and distress can be defined and measured in numerous ways. Digital Finance Analytics measures and tracks levels of household financial stress in Australia based on the cashflow of a household, (including its income, outgoings, and debt repayments).

36 Lowe, 'Household Debt, Housing Prices and Resilience', above n 3.

37 Ibid; Gill North, 'Well Governed, Sustainable and Socially Responsible Financial Corporations: Remote Or Real Expectations?' in Jean J du Plessis, Umakanth Varottil and Jeroen Veldman (eds), Globalisation of Corporate Social Responsibility and its Impact on Corporate Governance (Springer Publishing, Switzerland, 2017). 
government benefits, rapid and significant increases in loan interest rates, a recession, a housing or equity market crash, and/or a financial crisis. ${ }^{38}$

The precise trigger(s), timing and severity of such events are not entirely predictable, but should one or more of these scenarios occur, the number of Australian households affected, and the severity of the financial and social impacts on these households, could rise exponentially. The mounting levels of private debt in Australia are occurring in an economy with rising levels of inequality and wealth, ${ }^{39}$ stagnant wages, ${ }^{40}$ widespread use of part time and casual employment, and high housing costs. ${ }^{41}$ Segmental analysis of private debt in Australia indicates that the most leveraged households have a debt to disposable income ratio of more than six times and some low-income households are using more than 60 per cent of their disposable income to repay debt. ${ }^{42}$ Although many parts of the population have benefited from rising asset values and are in a healthy financial position overall, these capital accumulation benefits are unevenly dispersed, and the most indebted households commonly have negligible reserves or savings. ${ }^{43}$

Given these settings, it is vital to scrutinise the extent to which the responsible lending regimes in Australia are achieving their objectives. To do this, our study examined the strategy, focus and effectiveness of ASIC's supervision and enforcement. For readers that are not familiar with the relevant law, the regulation is outlined in Part IV of this article.

\section{B Outline of Study}

We searched the ASIC website ${ }^{44}$ to identify consumer credit industry reviews and enforcement actions initiated by ASIC involving the responsible lending provisions between January 2014 and the end of June 2017. This research found a total of 93 actions involving alleged or actual breaches of the responsible lending obligations. The study defines an 'action' as one of a series of the same type of action against a credit provider

38 The more significant negative consequences for households and nations arise from economic downturns that typically accompany such crises, including higher unemployment, reductions in the value of investment assets including housing and equities, reduced savings, lower consumption, and significant falls in business and consumer confidence: See, eg, Financial System Inquiry Final Report (The Australian Government the Treasury, November 2014) 33, 43-4, 47. See also Financial Service Inquiry Interim Report (The Australian Government the Treasury, July 2014), 2-57; Michael Thornley, 'Financial Stability Risk from Housing Market Cycles' (Bulletin Vol 79(12), Reserve Bank of New Zealand, July 2016).

39 Organisation for Economic Co-operation and Development, 'Focus on Top Incomes and Taxation in OECD Countries: Was the Crisis a Game Changer?' (May 2014) 3.

40 Philip Lowe, 'Resilience and Ongoing Challenges' (Speech delivered at the Urban Development Institute of Australia National Congress, Adelaide, 8 March 2016).

41 See, eg, Commonwealth Official Committee Hansard, Standing Committee of Economics, 24 February 2017, 1-4 (Philip Lowe).

42 Phillips and Taylor, above n 1, 12.

43 JCP Investment Partners, 'Investing in Practice: Over Capitalised, Over Extended ... LTI Overlooked?' (May 2017); Axelle Marjolin, Kristy Muir, Joana Ramia, Julian Trofimovs, and Abigail Powell, 'Why is Financial Stress on the Rise? Financial Resilience in 2016' (Report Part 1, Centre for Social Impact (CSI) and the National Australia Bank (NAB), September 2017) 9 , 22. A survey by the CSI and NAB found that 31.6 per cent of respondents had either no savings or less than a month of savings.

44 See Australian Securities and Investments Commission, Find a Media Release <http://asic.gov.au/about-asic/media-centre/find-a-media-release>. 
or credit assistance provider, such as one infringement notice or an obligation to refund money to customers. As indicated in Table 1 below, the loan products triggering the greatest number of responsible lending actions were SACC loans, car loans, and home loans. Together, these loan products comprised 88 per cent of the actions initiated by ASIC. To maintain a workable scope and clarity, our analysis in the following sub-parts focuses on these actions.

TABLE 1: RESPONSIBLE LENDING ACTIONS BY LOAN PRODUCT (JANUARY 2014JUNE 2017)

\begin{tabular}{|l|l|l|l|l|l|}
\hline $\begin{array}{c}\text { Total no. } \\
\text { responsible } \\
\text { lending } \\
\text { actions }\end{array}$ & $\begin{array}{c}\text { Small } \\
\text { amount } \\
\text { credit } \\
\text { contracts }\end{array}$ & Car loans & $\begin{array}{c}\text { Home } \\
\text { loans }\end{array}$ & $\begin{array}{c}\text { Overdraft } \\
\text { facilities }\end{array}$ & Credit Cards \\
\hline 93 & $40^{45}$ & $22^{46}$ & 20 & 9 & 2 \\
\hline
\end{tabular}

Table 2 shows that the types of credit providers and credit assistance providers most commonly involved were SACC providers, car loan brokers and financiers, and banks.

TABLE 2: RESPONSIBLE LENDING ACTIONS BY ENTITY TYPE (JANUARY 2014-JUNE 2017)

\begin{tabular}{|l|l|l|l|l|l|}
\hline $\begin{array}{c}\text { Total no. } \\
\text { responsible } \\
\text { lending } \\
\text { actions }\end{array}$ & $\begin{array}{c}\text { Small amount } \\
\text { credit contract } \\
\text { providers }\end{array}$ & $\begin{array}{c}\text { Car loan } \\
\text { brokers and } \\
\text { financiers }\end{array}$ & Banks & $\begin{array}{c}\text { Mortgage } \\
\text { brokers }\end{array}$ & $\begin{array}{c}\text { Non-bank } \\
\text { home loan } \\
\text { providers }\end{array}$ \\
\hline 93 & 40 & 22 & 19 & 9 & 3 \\
\hline
\end{tabular}

We discuss the home loan actions initially, because this area of lending is by far the most significant in Australia in terms of magnitude and materiality for both lenders and consumers. ${ }^{47}$ We then examine SACC related enforcement because the study found that the number of actions involving lenders in this sector was greatest and these borrowers are typically from the most indebted and vulnerable communities of the Australian

45 Thirty infringement notices were issued against Cash Converters involving total penalties of $\$ 1.35$ million. See ASIC, '16-380MR Cash Converters to Pay Over \$12M Following ASIC Probe' (Media Release, 9 November 2016) <http://asic.gov.au/about-asic/mediacentre/find-a-media-release/2016-releases/16-380mr-cash-converters-to-pay-over-12mfollowing-asic-probe/ $>$.

46 Twenty-two infringement notices were issued against BMW involving total penalties of $\$ 391$ 000. See ASIC, '16-019MR BMW Finance Pays $\$ 391,000$ Penalty for Breaching Responsible Lending and Repossession Laws' (Media Release, 2 February 2016) <http://asic.gov.au/about-asic/media-centre/find-a-media-release/2016-releases/16019mr-bmw-finance-pays-391-000-penalty-for-breaching-responsible-lending-andrepossession-laws/>.

47 Wayne Byres, 'Sound Lending Standards and Adequate Capital: Preconditions for Long-term Success' (Speech delivered at COBA and CEO \& Director Forum, 13 May 2015) 1. Australia's exposure to housing markets is large (both on an historical basis and relative to other jurisdictions). 
population. ${ }^{48}$ Lastly, we review the car loan actions because the level of enforcement across this industry was high and many of these consumers are also likely to come from highly indebted population segments. ${ }^{49}$ The actions taken by ASIC against credit providers and credit assistance providers from these three credit sectors are outlined chronologically to highlight the changing focuses of ASIC over the study period.

\section{Actions Involving Home Loans}

At the end of 2014, ASIC highlighted the potential vulnerability of interest only home loan borrowers to credit losses. It noted an 80 per cent growth in demand for interest only loans in the prior three years and a substantially higher average value of these loans than principal and interest loans. ${ }^{50}$ ASIC subsequently conducted a survey of lenders of interest only loans (including the big four banks) to identify conduct of concern and possible breaches of the responsible lending rules. ${ }^{51}$ ASIC found that many lenders were failing to consider whether this type of loan satisfied consumer needs, particularly in the medium to longer term. Specific issues included the period allowed for repayment of the loan principal, a lack of evidence about the borrower's requirements, and a failure to consider the borrower's actual living expenses. ASIC was concerned that many of these loans had been provided without regard for how borrowers would repay the loan principal. It also questioned the ability of these borrowers to afford the loans if interest rates were to rise. ${ }^{52}$

Of the 20 responsible lending regulatory actions taken by ASIC involving home loans, most concerned failures to assess the suitability of loans with respect to customer requirements and objectives and their financial situations. Other actions were initiated in response to advertisements that offered rapid loan approvals without completing the required due diligence to assess the suitability of the loans.

48 North, above n 2. See also Gill North, 'Small Amount Credit Contract Reforms: Will the Affordability Cap Achieve Its Intended Objectives Without Unintended Adverse Consequences?' (2017) 32 Australian Journal of Corporate Law 1; Gill North, 'Small Amount Credit Contract Reforms: Have Transparency and Competition Concerns Been Forgotten?' (2017) 25 Competition and Consumer Law Journal 101.

49 Ibid.

50 ASIC, 'Lenders to Improve Standards Following Interest-only Loan Review' (Media Release, 15-220MR, 20 August 2015) <http://asic.gov.au/about-asic/media-centre/find-a-mediarelease/2015-releases/15-220mr-lenders-to-improve-standards-following-interest-onlyloan-review $/>$.

51 Ibid.

52 Ibid. See also ASIC, 'Review of interest-only home loans' (Report 445, 20 August 2015) <http:/ / asic.gov.au/regulatory-resources/find-a-document/reports/rep-445-review-ofinterest-only-home-loans/ $>$. The ASIC industry study found that there was substantial variation in the way lenders applied interest rate buffers. On pages $48-51$ of Report 445 , ASIC discusses the ability of consumers with interest only loans to service their loans, including the buffers allowed for interest rate rises. ASIC notes that APRA has advised lenders that they should apply a minimum interest rate buffer of at least 2 per cent and a minimum floor rate of 7 per cent. It emphasises the need for more caution when the lenders have used a benchmark for estimating the expenses of a borrower and when the surplus calculated for a borrower's financial situation is low. 
- ASIC found that mortgage broker Parmjit Singh had failed to verify financial information and documents to support 40 loan applications to various banks. ASIC cancelled his credit licence. 53

- ASIC alleged that Interactive Brokers LLC, a US online brokerage firm, had issued retail margin loans without verifying customers' financial information. Interactive Brokers agreed to an enforceable undertaking with ASIC requiring it to refund $\$ 1.5$ million to customers under the supervision of PricewaterhouseCoopers, and to pay $\$ 100000$ to Financial Rights Legal Centre for consumer education. ${ }^{5}$

- ASIC criticised building society Wide Bay Australia Ltd for not properly assessing the suitability of loans. The building society had relied on limited information provided by a broker and had not checked the requirements and objectives of customers directly. Wide Bay agreed to improve its responsible lending practices. ${ }^{55}$

- ASIC expressed concerns to Bank of Queensland regarding its use of the Henderson Poverty Index as a benchmark to estimate customers' living expenses, without asking them about their actual expenses. The Bank agreed to update its home loan application forms and seek more information about the actual expenses of prospective borrowers. ${ }^{56}$

- ASIC bought actions against five mortgage broking firms targeting Chinese borrowers. The claims made in six advertisements of these companies were inconsistent with the duty to assess the suitability of loans for individual borrowers. In one case, the advertisement offered pre-approvals within 15 minutes, and in another claimed 'no proof of income required'. ASIC raised concerns on the basis that there had either been breaches of responsible lending obligations, misleading or deceptive advertising or false and misleading statements in advertising. The mortgage broking companies agreed to change their advertising. ${ }^{57}$

53 ASIC, 'ASIC Concerns about Loan Applications Result in Cancellation of Mortgage Brokers Licence' (Media Release, 14-030MR, 18 February 2014) <http://asic.gov.au/aboutasic/media-centre/find-a-media-release/2014-releases/14-030mr-asic-concerns-about-loanapplications-result-in-cancellation-of-mortgage-brokers-licence/ $>$. Counted as one action.

54 ASIC, 'ASIC Investigation Leads to Interactive Brokers Refunding \$1.5 million to Australian Customers' (Media Release, 14-336MR, 16 December 2014) <http://asic.gov.au/about$\mathrm{asic} / \mathrm{media}$-centre/find-a-media-release/2014-releases/14-336mr-asic-investigation-leadsto-interactive-brokers-refunding-15-million-to-australian-customers $/>$. Counted as two actions.

55 ASIC, 'ASIC Concerns Prompt Wide Bay to Review Lending Standards' (Media Release, 15013MR, 3 February 2015) <http://asic.gov.au/about-asic/media-centre/find-a-mediarelease/2015-releases/15-013mr-asic-concerns-prompt-wide-bay-to-review-lendingstandards $/>$. Counted as one action.

56 ASIC, 'ASIC Concerns Prompt Bank of Queensland to Improve Lending Practices' (Media Release, 15-125MR, 25 May 2015) <http://asic.gov.au/about-asic/media-centre/find-amedia-release/2015-releases/15-125mr-asic-concerns-prompt-bank-of-queensland-toimprove-lending-practices/>. Counted as one action.

57 ASIC, 'Mortgage Broking Firm Responds to ASIC's Concerns about Misleading Advertising in Chinese Language' (Media Release, 15-292MR, 13 October 2015) <http:/ / asic.gov.au/about-asic/media-centre/find-a-media-release/2015-releases/15- 
- In March 2017, ASIC alleged that Westpac had failed to properly assess the capacity of borrowers to meet their repayment obligations before entering into interest only home loan contracts during the period December 2011 to March 2015. Specifically, ASIC alleged that: Westpac used benchmark expenses instead of actual expenses to assess a customer's ability to repay; loans were approved where a proper assessment would have shown a monthly deficit for borrowers after making loan repayments; and the bank failed to adequately consider the impact of higher payments on borrowers after the interest only period. ASIC has commenced civil penalty proceedings against Westpac in the Federal Court. ${ }^{58}$

- ASIC announced on 3 April 2017, that following an examination of eight providers of interest only home loans (including six banks), ${ }^{59}$ it had required them to improve their practices when assessing a consumers' capacity to repay home loans. ASIC noted in its media release that ' $[r]$ ather than obtaining a single monthly living expense figure and then relying on a benchmark figure to assess suitability, borrowers' actual figures for different categories of living expenses (e.g. food, transport, insurance and entertainment) will now be obtained.' A remediation program was established allowing ASIC to continue to audit the lenders' processes. ${ }^{60}$

\section{Actions Involving SACC Loans}

Consumer credit regulatory protections are generally acknowledged as most important for disadvantaged or low-income consumers, and this is reflected in the actions taken by ASIC. ${ }^{61}$ ASIC has conducted two reviews of the SACC industry to assess compliance with the law. In its first review in 2011, ASIC found that lenders had introduced procedures to satisfy their responsible lending obligations, but also observed examples of lenders not documenting the purpose of loans, very limited verification of the financial circumstances of consumers, and a lack of response to conflicting information

292mr-mortgage-broking-firm-responds-to-asic-s-concerns-about-misleading-advertisingin-chinese-language/>; ASIC, 'ASIC Targets Misleading Chinese Language Home Loan Advertising' (Media Release, 16-212MR, 30 June 2016) <http://asic.gov.au/aboutasic/media-centre/find-a-media-release/2016-releases/16-212mr-asic-targets-misleadingchinese-language-home-loan-advertising/ $>$. Counted as six actions.

58 ASIC, 'ASIC Commences Civil Penalty Proceedings Against Westpac for Breaching Homeloan Responsible Lending Laws' (Media Release, 17-048MR, 1 March 2017) <http:/ / asic.gov.au/about-asic/media-centre/find-a-media-release/2017-releases/17048mr-asic-commences-civil-penalty-proceedings-against-westpac-for-breaching-homeloan-responsible-lending-laws $/>$. Counted as one action.

59 These six banks are ANZ, Commonwealth Bank, National Australia Bank, Bendigo and Adelaide Bank, ING Bank and Macquarie Bank.

60 ASIC, 'ASIC Announces Further Measures to Promote Responsible Lending in the Home Loan Sector' (Media Release, 17-095, 3 April 2017) <http://asic.gov.au/about-asic/mediacentre/find-a-media-release/2017-releases/17-095mr-asic-announces-further-measures-topromote-responsible-lending-in-the-home-loan-sector/ > . Counted as eight actions.

61 See, eg, Ali, Bourova and Ramsay, above n 27; Oren Bar-Gill and Elizabeth Warren, 'Making Credit Safer' (2008) 157 University of Pennsylvania Law Review 1; Raymond H Brescia, 'The Cost of Inequality: Social Distance, Predatory Conduct, and the Financial Crisis' (2010) 66 NYU Annual Survey of American Law 641. 
in loan applications. ${ }^{62}$ More worryingly, ASIC's later review in 2014 found industry wide weaknesses in documentation and record keeping, with little to no improvement since the earlier review. The associated report confirmed a range of failings around the responsible lending obligations. ${ }^{63}$ ASIC identified issues relating to the application of the rebuttable presumptions when a consumer has multiple SACC loans or a SACC loan in default and suggested some consumers may have been charged establishment fees where this was illegal or contrary to the policy rationales. ${ }^{64}$ It also found instances of lenders charging fees based on longer loan durations than requested by borrowers and the actual repayment periods. ${ }^{65}$

The 40 actions taken against SACC providers during the study period involved failures to assess the suitability of loans and the offering of loan products that were likely to be unsuitable. ${ }^{66}$

- An infringement notice was issued against Abaz Pty Ltd (trading as moneyplus.com.au) alleging that it failed to obtain bank statements from consumers covering at least a 90 day period to assess their capacity to repay. Abaz Pty Ltd paid the relevant penalty of $\$ 42500 .{ }^{67}$

- Net Finance Corp Pty Ltd was found by ASIC to have failed to make relevant inquiries and assessments in accordance with its responsible lending obligations, and to have assisted a consumer obtain a loan that was unsuitable. The company's credit licence was cancelled, its director was banned from

62 ASIC, 'Review of micro lenders' responsible lending conduct and disclosure obligations' (Report 254, 22 November 2011). <http://asic.gov.au/regulatory-resources/find-adocument/reports/rep-264-review-of-micro-lenders-responsible-lending-conduct-anddisclosure-obligations $/>$.

63 ASIC, 'Payday lenders and the new small amount lending provisions' (Report 426, 17 March 2015) [13]-[16] <http://download.asic.gov.au/media/3038267/rep-426-published-17march-2015.pdf>.

64 Ibid [31]-[33].

65 Ibid.

66 In February 2014, ASIC issued three infringement notices against Paid International Ltd (formerly First Stop Money Limited) for advertising 'instant decisions' and loan approvals 'within minutes'. These actions alleged a breach of section 12DB(1)(e) of the Australian Securities and Investment Commission Act 2001 (Cth) for false or misleading representations in advertising and were therefore excluded from the study count. However, the media release by ASIC explains that these actions were motivated by responsible lending concerns. Paid International Ltd paid the required penalties totalling \$30 600 on 14 March 2014. ASIC, 'Small Amount Lender Pays 30600 Dollar Penalty for Misleading Online Advertisements' (Media Release, 14-065MR, 2 April 2014) <http://asic.gov.au/about-asic/media-centre/find-amedia-release/2014-releases /14-065mr-small-amount-lender-pays-30600-dollar-penaltyfor-misleading-online-advertisements/>. Infringement notices D141599, D141603 and D141605.

67 ASIC, 'Payday Lender Penalised for Breaching New Responsible Lending Laws' (Media Release, 14-313MR, 25 November 2014) <http://asic.gov.au/about-asic/media-centre/finda-media-release / 2014-releases/14-313mr-payday-lender-penalised-for-breaching-newresponsible-lending-laws/ $>$. Counted as one action. Infringement notice C302730 for breach of section 130 National Consumer Credit Protections Act 2009 (Cth) failure to make inquiries and verifications. The penalty was paid on 15 October 2014 . 
working in the credit industry for 10 years, and an employee of the company was banned from working in the credit industry for eight years. 68

- In Australian Securities and Investments Commission $v$ The Cash Store Pty Ltd (in liq), ${ }^{69}$ (Cash Store case), ASIC commenced Federal Court proceedings against The Cash Store Pty Ltd as a loan originator providing credit assistance, and against Assistive Finance Australia Pty Ltd as a credit provider. The Court was asked to examine a sample of loan contracts and held that a majority of these involved failures to make a preliminary assessment of the suitability of the loans, failures to make reasonable inquiries about the customers' requirements and objectives, and failures to make reasonable inquiries about the customers' financial situations. ${ }^{70}$ The Federal Court awarded a total of $\$ 18.975$ million in penalties, including penalties of $\$ 10.725$ million against The Cash Store Pty Ltd and \$7.15 million against Assistive Finance Australia Pty Ltd. Davies J clarified the nature and scope of inquiries needed to satisfy the responsible lending requirements. His Honour indicated that making 'reasonable inquiries' requires more than a general statement of loan purpose. The loan purpose must be specific enough to enable the loans officer to understand the customer's requirements and objectives. For example, 'buying stuff for home' and 'travel' were found to be insufficiently specific but 'food' and 'work shoes' were held to satisfy the legal obligations. Reasonable inquiries as to customers' requirements and objectives also requires information about a customer's income and his or her fixed and variable expenses and other debts. ${ }^{71}$ Davies J acknowledged that the information required to assess a customer's financial situation 'will be a matter of degree in each particular case, ${ }^{72}$ but noted that in many of the sample contracts, there had been a failure to determine the customers' actual expenses and other debts. Loans had been advanced based solely on the capacity of customers to meet payments as demonstrated in their pay slips or Centrelink receipts.

- ASIC alleged that Money3 Corporations Limited (Money3) had offered a product that was unsuitable because compliance with its terms involved substantial hardship. The product was a loan with only two repayments, including a nominal repayment shortly after the loan had been taken out and a large second payment fifteen months later. In some instances, the second repayment comprised 170 per cent of the customers' Centrelink benefits for that pay period. As part of the settlement with ASIC, Money3 agreed to withdraw the relevant loan product and refund more than $\$ 100000$ to customers. ${ }^{73}$

68 ASIC, 'ASIC Cancels Credit Licence and Bans Director for 10 Years' (Media Release, 14312MR, 25 November 2014) <http://asic.gov.au/about-asic/media-centre/find-a-mediarelease/2014-releases/14-312mr-asic-cancels-credit-licence-and-bans-director-for-10years/ $>$. Counted as one action.

69 [2014] FCA 926. Counted as two actions.

70 ASIC, 'Federal Court Orders Record Penalty' (Media Release, 15-032MR, 19 February 2015) <http://asic.gov.au/about-asic/media-centre/find-a-media-release/2015-releases/15$032 \mathrm{mr}$-federal-court-orders-record-penalty/ $>$. Counted as two actions.

71 [2014] FCA $926[43]-[45]$.

72 [2014] FCA 926 [42].

73 ASIC, 'Money3 Provides Over $\$ 100,000$ in Refunds to Consumers as ASIC's Payday Lending Crackdown Continues' (Media Release, 15-168MR, 1 July 2015) <http:/ / asic.gov.au/about- 
- ASIC brought an action against Nimble Australia Pty Ltd (Nimble) alleging failures to properly assess the financial circumstances of its customers and failures to recognise customers with repeat SACC loans. ASIC found that Nimble had failed to make proper inquiries regarding customers' requirements and objectives and had relied on benchmark algorithms rather than seeking specific information about the financial position of consumers. Under the terms of an enforceable undertaking, Nimble was required to refund over 7000 customers a total of more than $\$ 1.5$ million, make a $\$ 50000$ contribution to Financial Counselling Australia, and engage an independent external compliance consultant to review its business practices and report back to ASIC on compliance. ${ }^{74}$

- ASIC initiated a series of actions against Cash Converters International Limited (Cash Converters) alleging failures to make reasonable inquiries around customers' income and expenses and failures to take reasonable steps to verify actual expenses. ASIC alleged that Cash Converters had relied on internally generated benchmarks to determine consumer expenses. ASIC issued 30 infringement notices and the company paid the relevant penalties totalling $\$ 1.35$ million. ${ }^{75}$ Cash Converters also agreed to an enforceable undertaking requiring it to refund customers $\$ 10.8$ million in fees and engage an independent expert to review its business operations and regulatory compliance. ${ }^{76}$

The Interim Report of the review of SACC law confirmed that the number of complaints received by the Credit and Investment Ombudsman involving responsible lending obligations was much higher for SACC lenders than for other credit sectors. ${ }^{77}$

asic/media-centre/ find-a-media-release/2015-releases/15-168mr-money3-provides-over100-000-in-refunds-to-consumers-as-asic-s-payday-lending-crackdown-continues $/>$.

Counted as one action.

74 ASIC, 'Payday Lender Nimble to Refund \$1.5 million Following ASIC Probe' (Media Release, 16-089MR, 23 March 2016) <http://asic.gov.au/about-asic/media-centre/find-a-mediarelease/2016-releases/16-089mr-payday-lender-nimble-to-refund-15-million-followingasic-probe/>; Enforceable Undertaking 029533337 by Nimble Australia Pty Ltd under s 322(1) of the NCCP dated 18 March 2016. Counted as three actions.

75 ASIC, 'Cash Converters to Pay Over \$12M Following ASIC Probe' (Media Release, 16-380MR, 9 November 2016) <http://asic.gov.au/about-asic/media-centre/find-a-mediarelease/2016-releases/16-380mr-cash-converters-to-pay-over-12m-following-asic-probe/>; Infringement Notices R20160000662849-R20160000662955 issued to Cash Converters Personal Finance Pty Ltd under s133 of the NCCP dated 10 October 2016; Infringement Notices R20160000662861-R20160000662961 issued to Cash Converters Personal Finance Pty Ltd under s131 of the NCCP dated 10 October 2016. Counted as 30 actions.

76 Enforceable Undertaking 029744238 by Cash Converters Personal Finance Pty Ltd and Cash Converters International Ltd under s 322(1) of the NCCP dated 4 November 2016. Counted as two actions.

77 Commonwealth Treasury Department, 'Review of The Small Amount Credit Contract Laws: Interim Report' (Report, December 2015) 8. Some SACC participants have acknowledged that the industry has compliance and reputational issues, and are responding positively. For example, Cash Converters indicated in its 2016 annual report that it needs to achieve a better balance between responsible lending, commercial objectives, and financial inclusion. The National Credit Providers Association board has also agreed to develop an industry code of conduct and has begun consultations with ASIC: Cash Converters, 2016 Annual Report 3; 
These complaints and the responsible lending actions taken by ASIC highlight systemic sector weaknesses around the required due diligence and record keeping obligations. Money3, Nimble and Cash Converters accounted for 77 per cent of the market share of the SACC industry in 2015, ${ }^{78}$ and ASIC has initiated responsible lending actions against each of these leading providers.

\section{E Actions Involving Car Loans}

The 22 responsible lending actions taken by ASIC against car loan providers and brokers involved failures to verify customers' financial positions, failures to assess suitability more generally (including requirements and objectives) and failures to have systems in place to ensure compliance with responsible lending rules. ${ }^{79}$

- ASIC alleged that Rosa Villella (trading as All Loans R Us) provided car loans without making reasonable inquiries about consumers' requirements and objectives or their financial situations. It cancelled the entity's credit licence. ${ }^{80}$

- ASIC brought actions against car loan broker, Fernando Morais, and his company Sanfern Pty Ltd, alleging that Morais had not made any inquiries or undertaken any checks into the accuracy of financial documentation provided and had not taken reasonable steps to verify information regarding customers' financial situations prior to conducting a preliminary assessment of loan suitability. Morais was banned from engaging in credit activities for ten years and the credit licence of Sanfern Pty Ltd was cancelled. 81

- An action by ASIC against car loan broker United Financial Services Pty Ltd (UFS) alleged that UFS had accepted false pay slips from a car dealership and had failed to have adequate risk management systems in place to detect fraud. Conditions were imposed on the credit licence of UFS requiring it to appoint an

NCPA, 'Small Loan Industry Association to Set Regulations for Loan Providers' (Media Release, 11 November 2016).

78 Commonwealth Treasury Department, 'Review of the Small Amount Credit Contract Laws Final Report' (Report, March 2016) 9.

79 ASIC alleged that Jeremy (WA) Pty Ltd breached s 12DB(1)(i) of the Australian Securities and Investments Commission Act 2001 (Cth) when it advertised 'guaranteed' car finance. These actions alleged false or misleading representations in advertising and were therefore excluded from the study count. However, once again, ASIC's media release explains that these actions were motivated by responsible lending concerns. ASIC issued two infringement notices against the company and Jeremy (WA) Pty Ltd paid the required penalties totalling $\$ 20$ 400: ASIC, 'Finance Broker Pays 20400 Dollars Infringement Notice Penalty' (Media Release, 14-022MR, 5 February 2014). <http:/ / asic.gov.au/about-asic/media-centre/find-amedia-release/2014-releases/14-022mr-finance-broker-pays-20400-dollars-infringementnotice-penalty/>. Infringement notices B667429 and B667435.

80 ASIC, 'ASIC Cancels Credit Licence of Victorian Credit Provider' (Media Release, 14-253MR, 26 September 2014) <http://asic.gov.au/about-asic/media-centre/find-a-mediarelease/2014-releases/14-253mr-asic-cancels-credit-licence-of-victorian-credit-provider/>. Counted as one action.

81 ASIC, 'ASIC Bans Former Car Loan Broker and Cancels Licence' (Media Release, 15-621MR 18 September 2015) <http://asic.gov.au/about-asic/media-centre/find-a-mediarelease/2015-releases/15-261mr-asic-bans-former-car-loan-broker-and-cancels-licence/>. Counted as one action. 
independent consultant to review its arrangements for verifying customer financial information and its monitoring and supervision of representatives. ${ }^{82}$

- ASIC alleged that Green Light Auto Group Pty Ltd (trading as Carboodle) lacked procedures to ensure compliance with responsible lending obligations. It imposed conditions on the credit licence of Carboodle requiring the appointment of an independent consultant to review its compliance arrangements. ${ }^{83}$

- ASIC issued 22 infringement notices against BMW Finance Australia Ltd (BMW), of which 6 were for alleged failures to make reasonable inquiries about, and failures to verify, the living expenses, income and cash of borrowers when there were unexplained discrepancies in the figures provided by customers. ASIC found that the company failed to assess contracts as unsuitable when the documentation showed insufficient income after deduction of expenses to meet loan repayments. BMW paid the infringement notice penalties totalling \$391 000 and was required to appoint a consultant to review its compliance with the law and internal company procedures and report back to ASIC. ${ }^{84}$

- Car loan lender, Channic Pty Ltd and car loan broker, Cash Brokers Pty Ltd, were found by the Federal Court to have breached responsible lending obligations by failing to assess the affordability and suitability of loans for vulnerable indigenous customers living in an isolated community. 85 These entities had offered 20 minute onsite loan approvals through a car sales yard. The Federal Court fined Channic \$278 000, Cash Brokers $\$ 278000$, and the sole director of both companies, Mr Hulbert, \$220 000.86

82 ASIC, 'ASIC Imposes Licence Conditions on United Financial Services Pty Ltd' (Media Release, 15-281MR, 1 October 2015) <http://asic.gov.au/about-asic/media-centre/find-amedia-release/2015-releases/15-281mr-asic-imposes-licence-conditions-on-unitedfinancial-services-pty-ltd/ $>$. Counted as one action.

83 ASIC, 'ASIC Imposes Licence Conditions on Car Financier' (Media Release, 15-299MR, 22 October 2015) <http://asic.gov.au/about-asic/media-centre/find-a-media-release/2015releases/15-299mr-asic-imposes-licence-conditions-on-car-financier/>. Counted as one action.

84 ASIC, ‘BMW Finance Pays $\$ 391,000$ Penalty for Breaching Responsible Lending and Repossession Laws' (Media Release, 16-019MR, 2 February 2016) < http:/ / asic.gov.au/aboutasic/media-centre/ find-a-media-release/2016-releases/16-019mr-bmw-finance-pays-391000-penalty-for-breaching-responsible-lending-and-repossession-laws/>. Counted as seven actions: Six infringement notices B1084381, B1084595, B1084625 dated 17 November 2015; and B1097324, B1103403, B1104045 dated 11 December 2015, for breaches of sections 130(1), 131(1), 133(1) of the NCCP; and one compliance review

85 ASIC, 'Cairns-based Car Yard Lender and Broker Breached Consumer Credit Laws' (Media Release, 16-335MR, 30 September 2016) <http:/ / asic.gov.au/about-asic/media-centre/finda-media-release/2016-releases /16-335mr-cairns-based-car-yard-lender-and-brokerbreached-consumer-credit-laws/ $>$. Counted as three actions.

86 Australian Securities and Investments Commission v Channic Pty Ltd (No 5) [2017] FCA 363. See also ASIC, 'Queensland Car Yard Lender Ordered to Pay Over \$1.2 Million After Breaching Consumer Credit Laws' (Media Release, 17-108MR, 7 April 2017) <http:/ / asic.gov.au/about-asic/media-centre/find-a-media-release/2017-releases/17108mr-queensland-car-yard-lender-ordered-to-pay-over-12-million-after-breachingconsumer-credit-laws $/>$. 
- A second action was initiated by ASIC against BMW Australia Finance Limited for causing hardship to customers due to failures to comply with responsible lending obligations between January 2011 and August 2016. As part of an enforceable agreement, BMW undertook to pay $\$ 14.6$ million in remediation payments, $\$ 7.6$ million in interest rate reductions, and $\$ 50$ million in loan write offs. It also agreed to make a $\$ 5$ million donation to consumer advocacy and financial literacy initiatives. ${ }^{87}$

- Following an investigation of its business practices, ASIC alleged that Motor Finance Wizard had failed to make reasonable inquiries about the income and expenses of customers and had failed to take steps to verify their expenses before issuing loans. Motor Finance Wizard agreed to an enforceable undertaking with ASIC requiring it: to write-off or refund $\$ 11$ million to consumers (including a re-assessment of each consumer's capacity to pay); to provide affected consumers with the option to terminate their consumer car lease or loan; and to pay $\$ 100000$ to a community benefit program that funds consumer initiatives. Motor Finance Wizard agreed that it would fulfill these obligations as part of a broader remediation program overseen by an independent auditor and engage an independent expert to review its operational compliance with consumer credit laws. ${ }^{88}$

\section{RESPONSIBLE LENDING REGIMES: THE REGULATION}

\section{A The Responsible Lending Rules (All Credit Providers)}

Regulation governing consumer credit was introduced by Australian states in the 1980s, with some harmonisation achieved through the implementation of a Uniform Consumer Credit Code. ${ }^{89}$ In 2008, the Council of Australian Governments agreed to move to a national consumer credit regulatory system in two phases, with the first phase including enactment of the NCCP. The NCCP expands the credit licensing regime to encompass

87 ASIC, 'ASIC Action Sees BMW Finance Pay $\$ 77$ Million in Australia's Largest Consumer Credit Remediation Program', (Media Release, 16-417MR, 6 December 2016) <http:/ / asic.gov.au/about-asic/media-centre/find-a-media-release/2016-releases/16417mr-asic-action-sees-bmw-finance-pay-77-million-in-australias-largest-consumer-creditremediation-program $/>$. Counted as four actions. ASIC alleged that BMW breached ss 128(d), 1430(1)(a), 130(1)(c), 131(1) and 133 (1) of the NCCP. Enforceable undertaking 029804328 accepted by ASIC on 2 December 2016.

88 ASIC, 'Motor Finance Wizard to Pay Over \$11 Million in Remediation Over Responsible Lending Concerns' (Media Release, 17-150MR, 24 May 2017) <http://asic.gov.au/aboutasic/media-centre/find-a-media-release/2017-releases/17-150mr-motor-finance-wizard-topay-over-11-million-in-remediation-over-responsible-lending-concerns $/>$. Counted as four actions. ASIC alleged that Motor Finance Wizard breached ss 130(1)(b), 130(1)(c), 133(1), 153(1)(b), 153(1)(c), 156(1) of the NCCP. Enforceable undertaking 029490310 accepted by ASIC on 23 May 2017.

89 The Uniform Consumer Credit Code ('UCCC') was enacted initially as the Consumer Credit (Queensland) Act 1994 (Qld). Equivalent legislation was then passed by other States and Territories. The UCCC scheme operated from 1996 until the commencement of the NCCP. 
those who provide credit or credit assistance, ${ }^{90}$ and includes responsible lending obligations and mandatory external dispute resolution scheme membership. ${ }^{91}$

The NCCP imposes responsible lending obligations on all participants involved in the provision of credit, including licensees that provide assistance in relation to credit contracts $^{92}$ and credit providers. ${ }^{93}$ Consumers may approach one or more credit providers (such as a bank) or credit assistance providers ${ }^{94}$ (such as brokers and intermediaries) directly or, may simultaneously approach both credit providers and credit assistance providers, and/or may use online loan comparator websites. ${ }^{95}$ After considering options, a consumer may submit a single formal application to a credit provider or credit assistance provider, or may submit multiple applications. Discussion with a potential consumer about the provision of credit by a licensed credit assistance provider (or an employee or representative of the intermediary) or a licensed entity that provides credit (or an employee or representative of the entity) may fall within the credit assistance provisions of the NCCP.

The responsible lending standards in the NCCP require a credit assistance provider to assess the suitability of a proposed loan and the borrower's capacity to repay it before providing credit. ${ }^{96}$ This preliminary assessment must be made within 90 days before the provision of credit, or within 120 days before the provision of credit for the purchase of residential property secured by a mortgage. ${ }^{97}$ The credit assistance provider must assess, and take reasonable steps to verify, the consumer's financial situation..$^{98}$ It must also make reasonable inquiries about the consumer's requirements and objectives. ${ }^{99}$ These responsible lending obligations apply to existing consumer credit contracts when consumers apply for an increase in a credit limit and to the provision of new credit to consumers.

Prior to formally offering a loan, a credit provider must assess the suitability of a proposed credit contract more comprehensively than may have occurred during a preliminary assessment. This final assessment encompasses three steps. The first step requires the credit provider to make reasonable inquiries concerning the consumer's requirements, objectives and financial situation. ${ }^{100}$ The second step requires the credit provider to ascertain the consumer's financial circumstances through reasonable inquiries, with a particular focus on the consumer's ability to meet repayments and

90 For background, see Bruce Taylor, 'New National Responsible Lending Obligations - Pt 1' (2011) 39 Australian Business Law Review 464; Bruce Taylor, 'New National Responsible Lending Obligations - Pt 2' (2012) 40 Australian Business Law Review 43.

91 The second phase of the reforms included measures to protect consumers in new credit categories including reverse mortgages, small amount credit contracts, and consumer leases. Detailed discussion of the reverse mortgage and consumer lease provisions is beyond the scope of this article.

92 NCCP pt 3.1

93 Ibid pt 3.2.

94 Ibid s 8

95 For a more detailed outline of Australian home loan participants and their roles, market, see ASIC, 'Review of Mortgage Broker Remuneration' (Report No 516, March 2017) 49-74.

96 NCCP ss 115-16, 128-31.

97 See National Consumer Credit Protection Regulations 2010 (Cth) s 26.

98 NCCP s 130.

99 Ibid ss 117-18.

100 Ibid s 130. 
liabilities under the proposed credit contract. ${ }^{101}$ Finally, the credit provider must take reasonable steps to independently verify the information provided by the consumer concerning their financial circumstances. ${ }^{102}$ A reasonable person test is applied and credit providers must undertake any inquiries that would ordinarily be carried out by a prudent lender in the circumstances. ${ }^{103}$ All credit licensees must follow these due diligence steps to confirm that a proposed contract is not 'unsuitable' for the consumer prior to issuing the loan. ${ }^{104}$ The NCCP requires licensees to keep a record of all materials that form the basis of a credit assessment and the consumer is entitled to request a copy of his or her assessment. ${ }^{105}$

Importantly, the credit contract must be assessed by the credit provider as 'unsuitable' if, at the time of the assessment, it is likely that the consumer will be unable to comply with the consumer's financial obligations under the contract, or could only comply with substantial hardship. ${ }^{106}$ If the consumer could only comply with the financial obligations under the contract by selling his or her principal place of residence, this is presumed to constitute 'substantial hardship' unless proven otherwise. The contract must also be assessed as 'unsuitable' if, at the time of the assessment, it does not meet the consumer's requirements or objectives. ${ }^{107}$

ASIC is responsible for administering the NCCP and has a broad range of powers and enforcement options. ${ }^{108}$ Failing to make the preliminary assessment, failing to make reasonable inquiries before undertaking the assessment, or failing to assess the credit contract as unsuitable where circumstances warrant such a finding can result in a civil pecuniary penalty. ASIC can apply for these pecuniary penalties within six years of the relevant contravention, 109 and can apply to the court for an injunction restraining conduct in contravention of the NCCP or mandating compliance with the NCCP. ${ }^{110}$ ASIC has further powers to impose conditions or penalties on a credit licensee, ${ }^{111}$ and to suspend, vary or cancel the credit licence of a lender for a failure to comply with the NCCP.112 Criminal penalties may apply where the consumer requests a copy of the suitability assessment and a credit provider or credit assistance provider fails to provide

\footnotetext{
101 Ibid s 130(1)(b)

102 Ibid s 130(1)(c).

103 Ibid s 130(1)(c).

104 Ibid s 131(1).

105 Ibid ss 120, 132. ASIC suggests consumers should be given sufficient information to enable them to check the factual basis of an assessment and query any inaccuracies. It notes that credit licensees are not expected to disclose commercially sensitive lending criteria on which a credit decision is based: ASIC, 'Credit Licensing: Responsible Lending Conduct' $\begin{array}{lllll}\text { (Regulatory Guide 209, November 2014) } 50 \text { [143]-[146] } & \text { [14 }\end{array}$ <http://www.asic.gov.au/media/2243019/rg209-published-5-november-2014.pdf>.

106 NCCP s 131(2)(a)

107 Ibid s 131(2)(b)

108 See Consumer Credit and Corporations Legislation Amendment (Enhancements) Act 2012 (Cth). The amendments were made to the NCCP.

109 NCCP s 167

110 Ibid s 177.

111 Ibid s 45.

112 Ibid div 6. See ASIC, 'Licensing: Administrative Action against Persons Engaging in Credit' Activities (Regulatory Guide 218, November 2010) 6-19.
} 
a written copy, or asks for payment; ${ }^{113}$ or the credit provider enters into a credit contract, or increases the credit limit of a credit contract, with a consumer for whom the contract is unsuitable. ${ }^{114}$ ASIC or a person who has suffered loss due to a contravention of the NCCP may apply to the court for an order for compensation within six years of the contravention.115

When alleged breaches of the NCCP are considered by ASIC to be less serious than those warranting court proceedings, ASIC has the power to issue an infringement notice within 12 months of the date on which the offence is alleged to have been committed. ${ }^{116}$ ASIC must have reasonable grounds to believe that the breach has occurred when issuing an infringement notice. The recipient of the notice can opt to pay the relevant penalty 117 and payment can be made without admitting liability. Once paid, ASIC publishes a copy of the notice and includes it on the ASIC credit infringement notices register. ${ }^{118}$ ASIC's power to issue infringement notices has been criticised as allowing the exercise of judicial power by an administrative body. ${ }^{119}$ However, recipients can refuse to pay the infringement notice penalty and ASIC must then consider whether to initiate civil penalty or criminal proceedings.

ASIC may also accept a written undertaking regarding matters in relation to which it has a function or power under the credit legislation. ${ }^{120}$ These undertakings are

113 NCCP ss 120(4) and s 132(5). The penalty is 50 penalty units and equates to a fine of $\$ 10500$ under the Crimes Act 1914 (Cth) (as amended by the Crimes Amendment (Penalty Unit) Act 2017 (Cth)).

114 NCCP s 133(6). The penalty is 100 penalty units and may result in a fine of $\$ 21000$, or 2 years imprisonment, or both, under the Crimes Act 1914 (Cth) (as amended by the Crimes Amendment (Penalty Unit) Act 2017 (Cth)).

115 NCCP ss 178-9. When a credit provider does not have resources to both pay a penalty and compensation, the NCCP requires the court to give preference to the order for compensation: NCCP s 181.

116 National Consumer Credit Protection Regulations 2010 (Cth) reg 39. See also ASIC, 'Licensing: Administrative Action against Persons Engaging in Credit Activities' (Regulatory Guide 218, November 2010), 16, 18. Regulatory Guide 218 indicates that the key factors ASIC considers in deciding to take administrative action include the nature and seriousness of the suspected misconduct, the state of the credit licensee's internal controls; conduct after the misconduct occurs, the previous regulatory record, and mitigating factors.

117 The infringement notice penalties are typically significantly less than the possible civil or criminal penalty.

118 ASIC, Credit and ASIC Act Infringement Notices Register (27 March 2018) $<$ http://asic.gov.au/online-services/search-asics-registers/additional-searches/creditand-asic-act-infringements-notices-register $/>$.

119 This criticism was made in the context of ASIC infringement notices under pt 9.4AA of the Corporations Act 2001 (Cth). See James McConvill, 'Australian Securities and Investments Commission's Proposed Power to Issue Infringement Notices: Another Slap in the Face to $\mathrm{s}$ 1324 of The Corporations Act or an Undermining of Corporate Civil Liberties?' (2003) 31 Australian Business Law Review 36; Tom Middleton, 'ASIC's Investigation and Enforcement Powers - Current Issues and Suggested Reforms' (2004) 22 Company and Securities Law Journal 503; Margaret Hyland, 'Infringement Notices under the Corporations Act 2001 (Cth): Has the Commonwealth Parliament Gone Too Far?' (2008) 10 University of Notre Dame Australia Law Review 115; Anne Rees, 'Infringement Notices and Federal Regulation: Wolves in Sheep's Clothing?' (2014) 42 Australian Business Law Review 276.

120 NCCP s 322(1). 
enforceable, and ASIC can apply to the court for an order when it considers the terms of an undertaking have been breached. ${ }^{121}$ An ASIC Guide indicates that an

enforceable undertaking can be initiated by a company, an individual or a responsible entity, or as a result of a discussion between that party and ASIC. [However, ASIC does] not have the power ... to require a person to enter into an enforceable undertaking. Similarly, a person cannot compel [ASIC] to accept an enforceable undertaking. ${ }^{122}$

There is considerable flexibility in the drafting of undertakings and there is no limit to the civil penalties that may be imposed. Once made, an undertaking is included on the ASIC enforceable undertakings register. ${ }^{123}$

While the National Credit Code (NCC) in sch 1 of the NCCP is not typically considered to form part of the responsible lending regimes, its provisions are closely linked and should be considered during loan suitability assessments. As ASIC notes in Report 516, the regulatory framework that sets out what must be done before providing credit or credit services in Australia includes the responsible lending obligations and the obligations in the NCC. ${ }^{124}$ The type of credit regulated under the NCC encompasses homes loans, personal loans, credit cards, consumer leases, and any credit product that is provided to individuals or strata corporations for personal, domestic or household purposes. ${ }^{125}$ The protections afforded to consumers under the NCC include default notice requirements and extended hardship provisions. ${ }^{126}$ Importantly, the NCC allows a borrower to initiate proceedings to re-open an unjust transaction. For instance, the consumer may allege that at the time the credit contract was entered, the credit provider knew, or could have ascertained by reasonable inquiry at the time, that the borrower could not pay in accordance with its terms or not without substantial hardship. On reopening the transaction, the court can order that the agreement be set aside, revised or altered, or that the borrower be relieved of the obligation to make any payment under the agreement. ${ }^{127}$

121 NCCP s 322(3).

122 ASIC, 'Enforceable Undertakings' (Regulatory Guide 100, February 2015) 6. See also ASIC, 'Licensing: Administrative Action against Persons Engaging in Credit Activities' (Regulatory Guide 218, November 2010).

123 ASIC, Enforceable Undertaking Register (26 April 2018) <http://asic.gov.au/onlineservices/search-asics-registers/additional-searches/enforceable-undertakings-register/>.

124 ASIC, 'Review of Mortgage Broker Remuneration' (Report 516, 17 March 2017) 37-8.

125 NCC ss 5(1)(a), 5(1)(b)(i) in sch 1 of the NCCP.

126 The NCC increased the maximum threshold for application of the hardship provisions from $\$ 312400$ to $\$ 500000$ and includes a power for this threshold to be raised. For an outline and analysis of these provisions, see Ali, Bourova and Ramsay, above n 27.

127 NCC ss 76-7 in sch 1 of the NCCP. Another area of law that is broadly connected to responsible lending concerns the reporting of credit information. Some of the leading credit providers in Australia continue to report only negative credit information, such as loan defaults, to credit bureaus. The Federal Government has therefore indicated that it intends to mandate comprehensive credit reporting by July 2018. The required reporting will include the provision of positive information such as a borrower's loan repayment history and credit limits. The Commonwealth Treasurer, the Hon Scott Morrison, expects these reforms to increase credit market competition and consumer access to finance. APRA hopes the reforms will improve credit risk assessments by credit providers: see Scott Morrison, 'Mandating Comprehensive Credit Reporting' (Media Release, 2 November 2017) <http://sjm.ministers.treasury.gov.au/media-release/110-2017/>; James Eyers, 'APRA to 


\section{B Home Loan Credit Providers}

When the form of credit sought is a standard home loan to purchase or refinance a residential property, the NCCP defines the credit product as a 'standard home loan'.128 To assist consumers to compare mortgage offerings or products at an early stage, standard home loan providers must supply a 'Key Facts Sheet' with up-to-date information, either in hard copy or on the company's website. ${ }^{129}$

Around 49 per cent of outstanding home loans in Australia are presently arranged through credit assistance providers (commonly referred to as mortgage brokers), while 52 per cent are sought directly from credit providers. ${ }^{130}$ When providing credit assistance, a licensee such as a mortgage broker must currently include the following in the credit proposal document:

- the total amount of fees or charges payable to the licensee;

- a reasonable estimate of the total commissions that the licensee and associates are likely to receive in relation to the credit contract; and

- a reasonable estimate of the total fees or charges payable to the credit provider or any other person in relation to the credit contract application. ${ }^{131}$

Continuing issues relating to mortgage broker remuneration prompted a comprehensive review by ASIC in 2016/17.132 In response, the Combined Industry Forum reported to the Government in December 2017 and has announced proposed measures to mitigate some of the issues raised by ASIC. 133

Importantly, the NCC extends to credit provided wholly or predominantly to purchase residential property for investment purposes, as well as to loans for renovating, improving and refinancing these properties. ${ }^{134}$ The term 'investment purposes' is not defined in the NCC, leaving its applicability to loans on residential

$<$ http:// www.apra.gov.au/adi/Publications/Pages/Quarterly-ADI-Property-Exposuresstatistics.aspx>.

131 NCCP s 121(2).

132 ASIC, 'Review of Mortgage Broker Remuneration' (Report 516, 16 March 2017). See also Explanatory Memorandum, National Consumer Credit Protection Bill 2009 (Cth) [3.11]; Gill North, 'Regulation Governing the Provision of Credit Assistance and Financial Advice in Australia: A Consumer's Perspective’ (2015) 43 Federal Law Review 369, 382-3.

133 Combined Industry Forum, 'Improving Customer Outcomes: The Combined Industry Forum Responses to ASIC Report 516: Review of Mortgage Broker Remuneration' (11 December 2017)

<https://www.ausbanking.org.au/images/uploads/CIF_Report_Submitted_281117.pdf>. The already broad scope of this article does not allow us to provide a detailed response to this report. But see the North article in the footnote above that discusses and critiques the differing obligations that apply to financial advisers and credit assistance providers in Australia. Our views correspond closely to those expressed in the North 2015 article.

134 NCC ss 5(1)(b)(ii)-(iii). 'Residential property' is defined in NCC s 204. 
property for investment in equities or other non-property related investments uncertain. ${ }^{135}$

\section{Small Amount Credit Contract Provides}

In 2012 the phase two credit reforms established a credit framework with tiered restrictions depending on the size of the loan. ${ }^{136}$ The regulatory tiers include SACCs, medium amount credit contracts, and other loans. A SACC is defined in the NCCP as a credit contract provided by an entity that is not an authorised deposit-taking institution, where the credit limit is less than $\$ 2000$, the term of the contact is at least 16 days but not longer than one year, the debtor's obligations under contract are unsecured, and the contract is not a continuing credit contract. ${ }^{137}$ A rebuttable presumption of unsuitability applies when providing SACC credit or increasing the loan limit for a consumer that has a SACC loan in default or is a debtor under two or more other SACCs in the prior 90 days. ${ }^{138}$ The NCCP also creates a special category of 'protected consumers' for persons who receive at least 50 per cent of their gross income as payments under the Social Security Act 1991 (Cth). ${ }^{139}$ SACC credit can only be provided to these consumers when total repayments under the contract (as well as repayment obligations under other SACCs the consumer may have) do not exceed 20 per cent of the consumer's gross income over the payment cycle. During the verification process, credit providers must obtain bank statements for accounts into which the customer's income is paid to verify their financial situation. ${ }^{140}$ To further protect consumers, a legislated warning must be displayed at shopfront premises and on websites, and must be read to the consumer when business is initiated by telephone. ${ }^{141}$

A review of the effectiveness of SACC law in Australia was completed in March 2016 and resulted in 24 recommendations. ${ }^{142}$ These recommendations seek to improve the affordability of the loans, ensure fair repayment schedules, and reduce the likelihood of consumers falling into debt traps and financial exclusion. On 28 November 2016, the Minister for Revenue and Financial Services, the Hon Kelly O'Dwyer, indicated that the Coalition Government accepted most of the review recommendations, although key recommendations including the disclosure of the annual percentage rates of SACC loans

135 The purchase of shares may fall within the term 'personal, domestic or household purposes'.

136 For a history of SACC lending in Australia, see Sally Anderson, 'Mapping the Terrain: The Last Decade of Payday Lending in Australia' (2001) 39 Australian Business Law Review 5; Sally Anderson, 'The Phenomenon of Payday Lending' (2013) 21 Australian Journal of Competition and Consumer Law 20.

137 NCCP s 5.

138 Ibid ss 131(3A), 133(3A).

139 Ibid s 133CC.

140 See ibid s 117(1A).

141 Ibid s 133CB.

142 The Treasury, Review of the Small Amount Credit Contract Laws (March 2016) <https://static.treasury.gov.au/uploads/sites/1/2017/06/C2016-016_SACC-FinalReport.pdf>. The 10 small amount credit contract (SACC) recommendations address the areas of affordability, suitability, early loan repayments, the timing of repayments, unsolicited offers, direct debit fees, a national SACC database, referral revenue, default fees, and a continued ban on credit contracts of less than 16 days. The six recommendations that apply to both SACCs and consumer leases deal with banks statements, documenting suitability assessments, warning statements, disclosure, penalties, and avoidance. 
and a cap on default charges were rejected. ${ }^{143}$ A Draft Bill reflecting this position was released for consultation on 23 October 2017.144

\section{Car Loan Providers}

There are no specific responsible lending rules applying to car loans or leases. Persons that use credit to enable them to purchase or lease a car may get a loan from a mainstream lender such as a bank or another class of lender or intermediary such as a SACC provider, or may apply for a loan or a lease from the car provider or associated financer. The amount and types of lending on cars and the characteristics of consumers using such loans are unknown, as specific data on this form of lending is not collected or published in Australia at present.

\section{E Regulatory Guidance}

ASIC has provided industry guidance and thereby nudged ${ }^{145}$ or persuaded lenders towards responsible lending standards. In November 2014, ASIC updated its Regulatory Guide 209 (RG 209) concerning responsible lending conduct. ${ }^{146}$ RG 209 indicates that the obligation to make reasonable inquiries is scalable and the steps required will vary depending on the circumstances. It suggests that the following factors are relevant to the scalability of the reasonable inquiries and verification obligations:

(a) the potential impacts on a consumer of entering into an unsuitable credit contract or consumer lease;

(b) the complexity of the credit contract or consumer lease;

(c) the capacity of the consumer to understand the credit contract or consumer lease; and

(d) whether the consumer is an existing or new customer. ${ }^{147}$

Consequently, more extensive inquiries are warranted when potential negative consequences for the consumer are highly material, the credit contract has complex terms, the consumer has limited capacity to understand the contract, or when the consumer is a new customer.

143 Kelly O'Dwyer, 'Government Response to the Final Report of the Review of the Small Amount Credit Contract Laws' (Media Release, 28 November 2016) <http:// kmo.ministers.treasury.gov.au/media-release/105-2016/>. For discussion on the existing rules governing small amount credit contracts and the proposed reforms, see North, 'Small Amount Credit Contract Reforms in Australia', above n 2. See also North, 'Small Amount Credit Contract Reforms: Will the Affordability Cap Achieve Its Intended Objectives Without Unintended Adverse Consequences?', above n 48; North, 'Small Amount Credit Contract Reforms: Have Transparency and Competition Concerns Been Forgotten?', above n 48.Currently, the primary form of regulatory protection in Australia for consumers of small amount credit contracts is price caps.

144 The Treasury, Small Amount Credit Contract and Consumer Lease Reforms (23 October 2017) <https://treasury.gov.au/consultation/c2017-t229374/>.

145 Richard H Thaler and Cass R Sunstein, Nudge: Improving Decisions about Health, Wealth and Happiness (Yale University Press, 2008).

146 ASIC, 'Credit Licensing: Responsible Lending Conduct' (Regulatory Guide 209, November 2014) <http://download.asic.gov.au/media/2243019/rg209-published-5-november2014.pdf>.

147 Ibid 12-14. 
RG 209 provides a list of possible inquiries about a consumer's financial situation that may be necessary for a credit provider or assister to make. The nature of these inquiries should encompass the personal and family circumstances of the consumer, the sources, level and reliability of their income, and the details of their fixed and discretionary expenses, asset ownership, and liabilities. ${ }^{148}$ Credit providers and assisters are required to obtain documentation to verify data provided by a customer. The relevant documentation may include bank records or statements, employer records, credit agency reports, and business records. ${ }^{149}$

RG 209 indicates that reasonable inquiries about a consumer's requirements and objectives should include the amount of credit sought, the credit timeframe, the purposes of the credit, the product features sought by the consumer, and the consumer's awareness and intentions with respect to possible associated expenses, such as insurance. ${ }^{150}$ As confirmed by the Federal Court in the Cash Store case, ASIC emphasises that descriptions of the consumer's reasons for requiring credit need to be specific and consistent with the amount of credit sought. 151

RG 209 suggests that factors that should be taken into account when considering whether a credit contract meets a consumer's requirements and objectives include: the nature of the credit; the relative importance of the consumer's requirements and objectives; the term of the credit relative to the life of a proposed asset purchase; the interest rate, fees and charges; the consumer's understanding of the proposed contract; and the possible need to finance a large final payment under the contract. ${ }^{152}$ RG 209 indicates that additional analysis is required when a consumer is involved with switching or refinancing activities, with a particular focus on the total cost savings for the consumer after taking into account all of the switching or financing fees and costs. ${ }^{153}$

RG 209 notes that ASIC expects credit providers to apply a degree of independent judgment to information provided by customers to establish that the information is reliable and credible. ${ }^{154}$ It suggests that further analysis is required if the consumer's income or expense levels are inconsistent with the consumer's type of employment and relevant benchmark levels. ${ }^{155}$ RG 209 confirms that lenders may use benchmarks (such as the Henderson Poverty Index plus a margin) but inquiries must still be made about a particular customer's income and expenses. ${ }^{156}$

As previously discussed, the provisions governing unsuitable credit in the NCCP are focused on 'substantial hardship' to an individual or household. ${ }^{157}$ RG 209 indicates that ASIC expects credit licensees to take a range of factors into account when considering whether a transaction is likely to result in substantial hardship. These factors include: a

148 Ibid $15-17$

149 Ibid 20-3.

150 Ibid 17-19.

151 Ibid 18.

152 Ibid 44

153 Ibid 47-8.

154 Ibid 21-2

155 Ibid 22

156 Ibid 37

157 As explained, the term 'substantial hardship' is not defined in the NCCP, but is presumed to occur if the consumer can only make the repayment by selling his or her principal place of residence: NCCP s 131(3). 
consumer's disposable income after expenses; the extent of the buffer between the level of disposable income and the required repayments under the credit contract; the consistency and reliability of the customer's income; whether the consumer's expenses are higher than average; whether the consumer is willing and able to reduce discretionary spending; consideration of the consumer's source of income and whether this includes social security payments; and whether assets may need to be sold to meet the repayment obligations. ${ }^{158}$

In August 2015, ASIC clarified the responsible lending obligations for credit providers of interest-only home loans in Report $445 .{ }^{159}$ Report 445 suggests that lenders need to ascertain and document the customers' reasons for selecting an interest only loan and how this form of loan meets their objectives, as well as the general purpose of the loan (for example to purchase a property). ${ }^{160}$ ASIC further details the required scope and content of inquiries into consumer requirements and objectives in Report 493. It notes that reasonable inquiries regarding a consumer's financial position should include assessment of the consumers' actual expenditure and should not rely solely on expenditure benchmarks. ${ }^{161}$

\section{F The Regulatory Responses of ASIC}

Having outlined the study and the relevant law, Tables 3 and 4 summarise the various actions taken by ASIC. As these tables demonstrate, ASIC used a hierarchy of regulatory responses to breaches or alleged breaches of the responsible lending obligations, and these varied by entity type and loan product.

TABLE 3: ASIC REGULATORY STRATEGIES BY ENTITY TYPE

\begin{tabular}{|l|l|l|l|l|l|}
\hline $\begin{array}{c}\text { Types of regulatory } \\
\text { strategy }\end{array}$ & $\begin{array}{c}\text { Small amount } \\
\text { credit } \\
\text { contracts }\end{array}$ & $\begin{array}{c}\text { Car loan } \\
\text { brokers and } \\
\text { financiers }\end{array}$ & Banks & $\begin{array}{c}\text { Mortgage } \\
\text { brokers }\end{array}$ & $\begin{array}{c}\text { Non-bank } \\
\text { lenders }\end{array}$ \\
\hline $\begin{array}{l}\text { Agree to cooperate/ } \\
\text { participate in } \\
\text { remediation process } \\
\text { and audit }\end{array}$ & & 8 & 6 & 3 \\
\hline $\begin{array}{l}\text { Undertaking to } \\
\text { appoint an } \\
\text { independent } \\
\text { compliance expert }\end{array}$ & 2 & 4 & & & \\
\hline Refund to customers & 3 & 5 & & 1 & \\
\hline
\end{tabular}

158 ASIC, 'Credit Licensing: Responsible Lending Conduct' (Regulatory Guide 209, November 2014) 36 <http://download.asic.gov.au/media/2243019/rg209-published-5-november2014.pdf>.

159 ASIC, 'Review of Interest-Only Home Loans' (Report 445, August 2015) <http://download.asic.gov.au/media/3329474/rep445-published-20-august-2015.pdf>.

$160 \operatorname{Ibid} 9$.

161 ASIC, 'Review of Interest-Only Home Loans: Mortgage Brokers' Inquiries into Consumer Requirements and Objectives' (Report 493, September 2016) 10 <http://download.asic.gov.au/media/4122413/rep-493-published-14-september-2016accessible.pdf $>$. 


\begin{tabular}{|l|l|l|l|l|l|}
\hline $\begin{array}{l}\text { Donation to financial } \\
\text { counselling and } \\
\text { literacy initiatives }\end{array}$ & 1 & 2 & 1 & 1 & \\
\hline $\begin{array}{l}\text { ASIC imposed } \\
\text { penalties }\end{array}$ & 31 & 6 & 9 & & \\
\hline $\begin{array}{l}\text { Court proceedings } \\
\text { and pecuniary } \\
\text { penalties }\end{array}$ & 2 & 3 & 1 & & \\
\hline $\begin{array}{l}\text { Cancellation of credit } \\
\text { licence }\end{array}$ & 1 & 2 & & 1 & 3 \\
\hline TOTAL (93) & 40 & 22 & 19 & 9 & 3 \\
\hline
\end{tabular}

TABLE 4: ASIC REGULATORY STRATEGIES BY LOAN PRODUCT

\begin{tabular}{|c|c|c|c|c|c|}
\hline $\begin{array}{l}\text { Types of } \\
\text { regulatory } \\
\text { strategy }\end{array}$ & $\begin{array}{l}\text { Small amount } \\
\text { credit } \\
\text { contracts }\end{array}$ & Car Loans & $\begin{array}{l}\text { Home } \\
\text { Loans }\end{array}$ & $\begin{array}{l}\text { Overdraft } \\
\text { facilities }\end{array}$ & $\begin{array}{l}\text { Credit } \\
\text { Cards }\end{array}$ \\
\hline $\begin{array}{l}\text { Agree to } \\
\text { cooperate/ } \\
\text { participate in } \\
\text { remediation } \\
\text { process and } \\
\text { audit }\end{array}$ & & & 16 & & 1 \\
\hline $\begin{array}{l}\text { Undertaking } \\
\text { to appoint an } \\
\text { independent } \\
\text { compliance } \\
\text { expert }\end{array}$ & 2 & 4 & & & \\
\hline $\begin{array}{l}\text { Refund to } \\
\text { customers }\end{array}$ & 3 & 5 & 1 & & \\
\hline $\begin{array}{l}\text { Donation to } \\
\text { financial } \\
\text { counselling } \\
\text { and literacy } \\
\text { initiatives }\end{array}$ & 1 & 2 & 1 & & 1 \\
\hline $\begin{array}{l}\text { ASIC imposed } \\
\text { penalties }\end{array}$ & 31 & 6 & & 9 & \\
\hline $\begin{array}{l}\text { Court } \\
\text { proceedings } \\
\text { and pecuniary } \\
\text { penalties }\end{array}$ & 2 & 3 & 1 & & \\
\hline $\begin{array}{l}\text { Cancellation of } \\
\text { credit licence }\end{array}$ & 1 & 2 & 1 & & \\
\hline TOTAL (93) & 40 & 22 & 20 & 9 & 2 \\
\hline
\end{tabular}




\section{RESPONSIBLE LENDING MODEL ANALYSIS}

\section{A Were the Actions Taken by ASIC under the Responsible Lending Regimes Sufficiently Timely and Substantive?}

The regulatory actions identified in our study encompass credit providers that operate as small businesses as well as the largest lending institutions, and they involve loans of short and long duration, loans of small and substantial amounts, and loans to households with widely varying incomes and financial capacity. The negative publicity and costs associated with these actions may deter further breaches, as all businesses are concerned about their reputation and brand. ${ }^{162}$ However, the strength of the deterrence value of public naming and shaming is likely to depend on the industry and lender involved. ${ }^{163}$ It is interesting to note the generally more collaborative approach ${ }^{164}$ taken by ASIC in response to breaches or alleged breaches of the responsible lending regimes by home loan providers, compared with the 'bigger stick' approach generally adopted with SACC loan and car loan providers (although admittedly Westpac is facing court proceedings relating to home mortgages and credit card lending).

These tiered regulatory responses by ASIC to responsible lending issues, including the provision of guidance and more formal responses, were consistent with the enforcement pyramid theory developed by Ayres and Braithwaite. A prior report on the performance of ASIC strongly criticised ASIC for being too reactive and suggested it needed to be more proactive and responsive. ${ }^{165}$ Our study and analysis suggests ASIC has responded positively to this criticism. Since 2014, it has used a variety of proactive, flexible and less intrusive approaches in response to responsible lending concerns, such as industry reviews, the provision of ongoing guidance, and the establishment of continuing surveillance and remediation programs. ${ }^{166}$ At the same time, ASIC has initiated court proceedings and cancelled credit licenses when required.

162 Bronwen Morgan and Karen Yeung, An Introduction to Law and Regulation: Text and Materials (Cambridge University Press, 2007) 101.

163 A-M Nienaber, M Hofeditz and R H Searle, 'Do we Bank on Regulation or Reputation? A Meta-Analysis and Meta-Regression of Organizational Trust in the Financial Services Sector' (2014) 32 International Journal of Bank Marketing 367, 378. See also Gunther Teubner, 'Substantive and Reflexive Elements in Modern Law' (1983) 17 Law \& Society Review 239; Hugh Collins, 'Regulating Contract Law' in Christine Parker et al (eds), Regulating Law (Oxford University Press, 2004) 13, 24.

164 For example, the remediation process in which six banks and two non-bank lenders have engaged: ASIC, 'ASIC Announces Further Measures To Promote Responsible Lending In The Home Sector', (Media Release, 17-095MR, 3 April 2017) <http://asic.gov.au/aboutasic/media-centre/find-a-media-release/2017-releases/17-095mr-asic-announces-furthermeasures-to-promote-responsible-lending-in-the-home-loan-sector/>.

165 Commonwealth of Australia, above n 24. See also Comino, above n 22.

166 See, eg, ASIC, 'ASIC Announces Further Measures to Promote Responsible Lending in the Home Loan Sector' (Media Release, 17-095MR, 3 April 2017) <http://asic.gov.au/aboutasic/media-centre/find-a-media-release/2017-releases/17-095mr-asic-announces-furthermeasures-to-promote-responsible-lending-in-the-home-loan-sector/>; ASIC, 'Motor Finance Wizard to Pay Over \$11 Million in Remediation Over Responsible Lending Concerns' (Media Release, 17-150MR, 24 May 2017) <http://asic.gov.au/about-asic/media-centre/find-amedia-release/2017-releases/17-150mr-motor-finance-wizard-to-pay-over-11-million-inremediation-over-responsible-lending-concerns/>. 
The reasons why ASIC adopted its strategic approach are likely to be multifaceted, and may reflect the nature of the relevant business, the characteristics, position and capacity of the borrowers, ${ }^{167}$ the cost of the loans, and the reputation and state of competition in the industry. For example, one can argue for heightened and proactive regulatory supervision of responsible lending practices by ASIC in the SACC market. Scholarly studies have found that providers of short-term, high cost loans commonly target the most vulnerable and disadvantaged parts of the community, with stores that offer these credit products over-represented in the lowest socio-economic areas. ${ }^{168}$ These low income and disadvantaged consumers are most likely to be excluded from access to basic mainstream credit products ${ }^{169}$ and are also least likely to benefit from disclosure regulation. In addition, the absolute and relative cost of these loans is high, the level of price competition is minimal, and the ability and capacity of these consumers to search for the most appropriate loan is limited. ${ }^{170}$ Similarly, responsible lending of car finance is important, because a car may be the single largest asset of some borrowers and may be necessary to retain employment. In contrast, there is a reasonable level of competition in the Australian home loan market and some of these borrowers are better able to shop around for a loan that best suits their needs. Given these important credit segment and borrower differences, the review by ASIC of the SACC and car loan markets, and the later and more limited focus on home lending, are understandable. One can legitimately argue that home loan borrowers should be afforded less regulatory protection and should remain more culpable for their credit decisions than SACC and car loan consumers (particularly when using these loans to acquire investment properties and gain taxpayer concessions to enhance their returns).

Notwithstanding the highlighted positive developments, we question the timeliness and sufficiency of ASIC's responses to responsible lending issues, particularly in the area of home loans. Interest only home loans in Australia comprised more than 40 per cent of total residential mortgages outstanding at the end of $2014 .{ }^{171}$ Given the magnitude and inherent risks of these loans, it was appropriate for ASIC to review the lending standards of this segment. Yet ASIC's review of the interest only home loan sector was not conducted until 2014/2015, and by this time, the levels of outstanding loans were already high,, 72 and households were already committed to repayments that were potentially 'not suitable'. As discussed earlier, ASIC identified systemic issues regarding inadequate consideration by lenders of actual customer expenses, the ability of

167 Connolly, above n 6; Muir, Marjolin and Adams, above n 6.

168 See, eg, Paul Ali, Cosima Hay McRae and Ian Ramsay, 'Payday Lending Regulation and Borrower Vulnerability in the UK and Australia' (2015) 3 Journal of Business Law 223, 230; Scott Carrell and Jonathan Zinman, 'In Harm's Way? Payday Loan Access and Military Personnel Performance' (2014) 27 Review of Financial Studies 2805, 2806, 2829. See also Paul Ali, Cosima Hay McCrae and Ian Ramsay, 'The Politics of Payday Lending Regulation in Australia' (2014) 39 Monash University Law Review 411, 413, 426; Andrew J Serpell, 'Protecting the Desperate: The Regulation of Payday Lending' (2015) 43 Federal Law Review 147, 172.

169 Muir, Marjolin and Adams, above n 6.

170 See North, 'Small Amount Credit Contract Reforms: Have Transparency and Competition Concerns Been Forgotten?', above n 48.

171 APRA, ADI Quarterly Property Exposures June 2017 (29 August 2017) http://www.apra.gov.au/adi/Publications/Documents/QPEX_June_2017.pdf. In December 2014, interest only home loans issued by ADIs totalled $\$ 481437$ million. By June 2017, the equivalent figure was $\$ 580989$ million. Ibid. 
borrowers to repay the loan principal, and the capacity of borrowers to cope with rising interest rates. Segmental analysis of proprietary data provided by Digital Finance Analytics suggests that the households with an interest only loan who remain most exposed include young families buying their first home and more affluent households with one or more investment properties. ${ }^{173}$

Other residential property loans that are commonly considered to be risky, but which have not been systematically reviewed by ASIC, are home loans for investment purposes that comprise 35 per cent of outstanding home loans. ${ }^{174}$ There is international evidence suggesting people who acquire residential properties for investment purposes are more likely to default on loans than owner occupiers, ${ }^{175}$ so it is surprising that ASIC has not reviewed the lending standards across this segment (other than investment related mortgages structured on an interest only basis). ${ }^{176}$ It is also surprising that RG 209 does not provide guidance on the required differences, if any, in the responsible lending due diligence processes when mortgage credit is provided for investment purposes. More broadly, it appears that ASIC has not comprehensively reviewed the responsible lending standards applied to owner occupier home loans, even though this is the largest segment of outstanding home loans and the single most material credit product in Australia. ${ }^{177}$

\section{B Allocation of Lender and Borrower Responsibilities for Credit Decisions}

Debates concerning the appropriate policy balance between the legal responsibilities of lenders to determine the suitability and affordability of consumer loans and the responsibilities of consumers for their credit decisions are ongoing. ${ }^{178} \mathrm{It}$ is, and will always be, important for consumers to take some degree of personal responsibility for their financial decisions and overall financial position. However, the credit regulatory settings in Australia acknowledge and reflect the market failures that commonly arise in consumer credit markets. ${ }^{179}$ As scholarly and other commentators highlight, lenders are

173 Elizabeth Knight, 'Not in Their Interest: The Home Loan Borrowers that Have Been Left Out to Dry', Sydney Morning Herald (online) 24 June 2017 <http://www.smh.com.au/business/banking-and-finance/not-in-their-interest-the-homeloan-borrowers-that-have-been-left-out-to-dry-20170623-gwx2dn.html>.

174 APRA, above $\mathrm{n}$ 171. In June 2017, investment related mortgages issued by ADIs totalled $\$ 535,684$ million. The proportion of investor housing loans in the United Kingdom is around 17 per cent and the authorities there are concerned about the risks associated with these loans: Bank of England, Financial Stability Report (Issue No 39, June 2016) vi, 13.

175 Thornley, above n 38; Robert Kelly, 'The Good, the Bad, the Impaired: A Credit Risk Model of the Irish Mortgage Market' (Central Bank of Ireland Technical Paper 13/RT/11, 2011).

176 The publicly available statistics from APRA on interest only home loans in Australia are not split into owner occupier and investment related. Similarly, the statistics on investment related home loans from APRA and the RBA are not split by loan structure.

177 APRA, above $\mathrm{n}$ 171. In June 2017, owner occupier mortgages issued by ADIs totalled \$1 006 24 million.

178 See, eg, Geoffrey Christopher Rapp, 'The Wreckage of Recklessness' (2008) 86 Washington University Law Review 111; Pottow, above n 30, 405; Therese Wilson, 'The Responsible Lending Response' in Therese Wilson (ed), International Responses to Issues of Credit and Overindebtedness in the Wake of Crisis (Ashgate, 2013) 109; RP Goodwin-Groen and M Kelly-Louw, The National Credit Act and its Regulations in the Context of Access to Finance in South Africa (Finmark Trust, 2006).

179 See, eg, Ramsay, 'Consumer Credit Law, Distributive Justice and the Welfare State', above n 27; Udo Reifner et al, 'Consumer Overindebtedness and Consumer Law in the European 
often in a better position than consumers to objectively assess credit risks and the suitability and affordability of loans. ${ }^{180}$ Lenders generally have substantive industry and consumer credit databases and accumulated experience of credit markets that allow more sophisticated and reliable assessments of a borrower's financial position and capacity to repay the loan. Second, there are significant imbalances in the allocation of risk between Australian lenders and borrowers. For example, home loans are made on a secured basis as part of a diversified portfolio and the riskiest classes of these loans are supported by mortgage lending insurance. These insurance policies are paid for by the borrower, but protect the lending institution when the borrower defaults and proceeds from the sale of the property and other sources are insufficient to repay the loan. ${ }^{181}$ Similarly, it is likely that many car loans in Australia are secured. ${ }^{182}$ SACC providers also mitigate their risks by requiring consumers to provide direct debit access to their bank account, thereby allowing the lender to gain priority access to incoming funds. ${ }^{183}$ Third, the optimistic bias of many consumers is well documented and acknowledged. The tendency of consumers to purchase items on credit today without an understanding or thought of future repercussions are recurring patterns in global credit markets. ${ }^{184}$ For home loan borrowers in Australia, these positive biases have been strongly reinforced by the longstanding upward trajectory of house prices (especially in Sydney and Melbourne) and a belief by some borrowers that house prices cannot, or are unlikely to, fall. The capacity of many households to objectively comprehend and assess their overall financial positions and risks is therefore likely to be lower than many imagine. ${ }^{185}$ Many Australian borrowers are swayed by a deep-seated aspiration to own a home, a desire to benefit alongside others from rising investment markets, and the appeals of consumerism. Moreover, these aspirations and tendencies are deeply entrenched across the general population and are encouraged by powerful constituencies.

The effects, if not the explicit aims, of the responsible lending rules are a rebalancing of the considerable information, power, and risk asymmetries between lenders and borrowers. While the behavioural biases of consumers were probably not significant factors in the minds of policy makers when the responsible lending policy was introduced, the effective shift in allocation of responsibilities from borrowers to lenders reflects the many intellectual, behavioural and motivational difficulties faced by consumers when making complex credit and financial decisions.

Union' (Final Report presented to the Commission of the European Communities, Health and Consumer Protection Directorate-General, September 2003); Ali, Bourova and Ramsay, above $\mathrm{n} 27$.

180 See, eg, Bar-Gill, 'Seduction by Plastic', above n 30, 1375; Pottow, above n 30, 431.

181 See North, 'Regulation Governing the Provision of Credit Assistance \& Financial Advice in Australia: A Consumer's Perspective', above n 132, 373-4.

182 See Treanor, above n 20

183 North, 'Small Amount Credit Contract Reforms in Australia', above n 2, 218.

184 See, eg, Neil D Weinstein, 'Unrealistic Optimism About Future Life Events' (1980) 39 Journal of Personality and Society Psychology 806; Cass R Sunstein, Christine Jolls and Richard H Thaler, 'A Behavioural Approach to Law and Economics' (1998) 50 Stanford Law Review 1471; BarGill, above n 30; David Laibson, 'Golden Eggs and Hyperbolic Discounting' (1997) 112 Quarterly Journal of Economics 443; Pottow, above n 30. See also Ramsay, above n 30, 73.

185 Notably, the proportion of home loan borrowers in Australia with an education limited to high school at the end of October 2017 was 79.4 per cent: Digital Finance Analytics proprietary data. 


\section{Responsible Lending Regulation: Our Predictions and Proposed Reforms}

Although many lenders and others likely presume that most outstanding household debt in Australia will be fully repaid, repayment outcomes may depend on the efficacy of the responsible lending rules and remedies. As previously explained, ASIC or a person who has suffered loss as a result of a contravention of the NCCP may apply to the court for an order for compensation within six years of the contravention. 186 Additionally, where borrowers can show that a loan covered by the NCC was issued without sufficient consideration of its suitability and the capacity of the consumer to repay it without substantial hardship, the court has powers to set aside, revise or alter the loan contract, and can relieve the borrower from their contractual obligations. These powers, and the response of the courts to consumers who have been given loans well beyond their capacity to reasonably repay them, are expected to feature prominently in future decades. The ability of the courts to consider personal responsibility factors such as the type of loan and financial capacity of the borrower will be limited as the responsible lending rules are essentially procedural in nature. Although the substantial hardship presumption applies only to loss of the main residence, where borrowers have used equity on their principal place of residence to acquire one or more investment properties, these consumers are still afforded legal protection. The case law outlined earlier demonstrates that compliance or otherwise often depends on available documentation concerning the borrower's objectives and requirements and capacity to repay the loan.

Concerns regarding the capacity of Australian households to repay loans when adverse changes or circumstances occur are heightened by recent empirical evidence. UBS, a global investment bank, conducts online surveys of home loan borrowers in Australia. Its latest survey of 900 households with a home loan issued during 2016/2017 found that a significant proportion admitted that they had overstated their income and or understated their expenses on the mortgage applications. ${ }^{187}$ Most notably, 37 per cent of those who used a mortgage broker had been encouraged by the broker to misrepresent their application. ${ }^{188}$ These practices are factors that are likely to be considered by the courts in future responsible lending actions. Where credit assisters have encouraged borrowers to misstate items on the loan applications or have fraudulently changed items, and even when the borrowers themselves misstate personal information, the courts will be required to scrutinise the information verification processes of the credit providers.

We suggest the responsible lending model in Australia is sound, but insufficient, in a country that has become accustomed, and even addicted to, the use of credit, without careful regard for the longer term consequences. We propose modest reforms to this

186 NCCP ss 177-8. When a credit provider does not have resources to both pay a penalty and compensation, the NCCP requires the court to give preference to the order for compensation: NCCP s 181.

187 UBS, 'Australian Banking Sector Update UBS Evidence Lab - \$500 billion in “Liar Loans”?' (11 September 2017) 8. 15 per cent of respondents stated that they over-represented their household income, 16 per cent over-declared other assets, 15 per cent under-represented other loans or commitments, and 30 per cent under-represented their living costs.

188 Ibid. See also Michael Janda, 'Mortgage Fraud: \$500b of 'Liar Loans" in Australia, Warns Investment Bank UBS', ABC News (online), 14 September 2017 $<$ http:/ / www.abc.net.au/news/2017-09-11/500b-dollars-of-liar-loans-in-australiaubs/8892030>. 
model to ensure a more effective supervisory framework and enhanced consumer credit protections. First, to achieve the policy aims, monitoring and enforcement of the responsible lending standards by ASIC should be methodical, comprehensive and ongoing during all stages of credit cycles, with especially strong interventions at the beginning of cycles to ensure prudent lending standards are established, and then maintained. Second, we recommend the introduction of mandatory online warnings on lender websites that warn borrowers that their employment and other personal conditions may deteriorate, interest rates may rise, and asset prices (including the prices of houses and cars) may decline significantly. Lender websites are the most common source of information used by consumers when considering home loans and personal loans, so the accuracy, balance and usefulness of these sites are critical. ${ }^{189}$ Some borrowers may not fully comprehend the proposed website facilities due to financial literacy concerns. ${ }^{190}$ To mitigate these issues, the websites should assess borrower understanding using consumer testing. ${ }^{191}$ Third, credit providers and intermediaries should be required to provide online sensitivity calculators to enable consumers to assess the impacts of adverse personal and external factors (including the cumulative effect of several changes) on their ability to repay the loan. ${ }^{192}$ The cost and effort to introduce such warnings and calculators across the industry is not expected to be significant and these endeavours would encourage further debate on appropriate lending standards. Lenders should notify prospective borrowers about the warnings and calculator facilities prior to completion of a loan contract and should be required to engage with the borrower about the risks involved, including disclosure of the actual

189 ASIC, 'Australian Financial Attitudes and Behavioural Tracker' (Report 541, March 2017) 44.

190 See Kathleen C Engel, 'Can Consumer Law Solve the Problem of Complexity in U.S. Consumer Credit Products?' (Research Paper No 14-34, Suffolk University Law School, 21 November 2014) 2, <http://papers.ssrn.com/sol3/papers.cfm?abstract_id=2529148>. See also North, 'Small Amount Credit Contract Reforms in Australia', above n 2, 218-19. The North empirical study found that households from the more affluent and well-educated population segments were generally more aware of the disclosure of the annual percentage rates (APRs) of loans, understood their role and nature, and found they were useful when comparing loan offerings. While less affluent households and those in either financial distress or under financial stress were less likely to comprehend APRs and use them when seeking credit, positive responses were received across all segments, suggesting disclosure is effective, albeit to a varying extent depending on the borrower's characteristics.

191 This approach was used by the Competition and Markets Authority and the Financial Conduct Authority in the United Kingdom when enacting rules relating to payday loans price comparison websites: see Financial Conduct Authority, Consumer Credit: Proposals in Response to the CMA's Recommendations on High-Cost Short-Term Credit (October 2015) 11-12. See also Lauren E Willis, 'The Consumer Financial Protection Bureau and the Quest for Consumer Comprehension' (2017) 3(1) The Russell Sage Foundation Journal of the Social Sciences 74.

192 ASIC provides a series of online calculators on their MoneySmart website that consumers can use to budget and assess their financial capacity to repay a mortgage and other debt. See ASIC, Calculators $\mathcal{E}$ Resources (21 September 2017) <https://www.moneysmart.gov.au/tools-and-resources>. While these facilities are commendable and could be adapted for the proposed lender websites, the share of credit consumers using these sites is low and the ASIC calculators do not warn consumers about the need to include a buffer for adverse events or provide examples of the sensitivities of a household to a series of unexpected contingencies: ASIC, 'Australian Financial Attitudes and Behavioural Tracker', above n 189, 44. 
buffer levels allowed for interest rates rises and other contingencies. As discussed, there are recognised shortcoming with disclosure regimes, especially for consumers who are desperate for funds or perceive an immediate need for goods or services. ${ }^{193}$ However, disclosure regimes are more effective when supported by other legal and market based mechanisms. Disclosure by lenders of the buffers allowed in the lending assessments would reinforce the efficacy of online warnings and calculators and would assist borrowers to consider the impacts of specific risks and events. This disclosure obligation would also enhance market transparency and enable more comprehensive scrutiny of industry lending standards. The proposed disclosure coupled with more comprehensive monitoring and enforcement would further encourage greater compliance with responsible lending regulation.

\section{CONCLUSION}

Historical events and patterns point to the importance of strong supervision and enforcement of responsible lending regimes, particularly during periods of strong credit growth and rising asset prices. It is critical that potentially harmful debt does not accumulate within households to a point where they become financially stressed while their personal circumstances and economic conditions are still relatively positive, as this leaves no financial buffer or room to manoeuvre when these circumstances and conditions deteriorate. Our study suggests ASIC may have been caught off-guard by the lending standards and practices revealed through its surveys of SACC lending and interest only home loans. More positively, ASIC used the data gathered from these surveys to detect and enforce alleged or actual breaches of the responsible lending rules. The study demonstrates that ASIC used the various powers available to it, including low level and more intrusive responses and the provision of guidance on expected responsible lending standards and practices. Moreover, ASIC's regulatory responses were strategic, with the greatest number of actions and the most severe penalties applied against credit providers that commonly provide loans to the most disadvantaged sections of the community, that are not supervised by the Australian Prudential Regulation Authority (APRA), and that operate largely in the shadows. These actions by ASIC against non-mainstream lenders, such as SACC lenders and car loan providers and brokers, were appropriate given the poor transparency of these industries and the need to protect vulnerable groups from being targeted by lenders with potentially harmful products.

The timing, scale and sufficiency of ASIC's responses to breaches of responsible lending obligations across the home loan sector are more problematic, given the materiality of residential property construction, ownership and debt in Australia. ${ }^{194}$ ASIC has shown that it is willing to hold the largest banks to account, with an ongoing court action against Westpac alleging non-compliance with the responsible lending

193 Howells, above n 29, 357. See also North, 'Small Amount Credit Contract Reforms in Australia', above n 2, 209-10. A survey of households using SACC loans in Australia found that 58.7 per cent indicated it was the only credit option available, 28.0 per cent thought this source of funds was convenient, and 13.3 per cent said they sought the loans out of desperation.

194 Lowe, 'Household Debt, Housing Prices and Resilience', above n 3. Lowe confirms that the upswing in residential construction activity has substantively supported the Australian economy over recent years. 
obligations when issuing home loans. ${ }^{195}$ Its continued surveillance of six banks and two non-bank lenders of interest only loans through a remediation and audit process also demonstrates continuing attention to the need for responsible conduct regarding residential property lending. Yet ASIC's reviews of the home loan sector appear to have been limited to interest only loans and its review of these loans was not until the end of 2014. There is no evidence that ASIC has systematically reviewed the standards of responsible lending across the owner occupier and investment property home loan segments, or engaged with these lenders on either a proactive or punitive basis, despite the enormity of these exposures and risks for many households and for the broader economy.

Consequently, the pressing question for all Australians is whether the investigations by ASIC of responsible lending and its regulatory responses and enforcement actions have been sufficiently timely, broad and substantive. The adequacy or otherwise of these regulatory interventions will only be fully assessable at the final stages of the present economic, credit and housing cycles. One hopes that the prolonged period of reliance on consumer credit in Australia will end in an orderly fashion, but this seems increasingly unlikely as the levels of household debt and the housing and equity markets continue to break new records. When the next financial, housing or credit crisis occurs either in Australia or on a broader basis (and the real question is when this will occur, rather than iff, 196 commentators will no doubt reflect on its causes. While many are likely to blame ASIC for not doing more, the participants in, and beneficiaries of, the present credit boom are many, 197 and the pressures for these participants and beneficiaries to opt for short term gains today, without full consideration of the longer-term consequences, are immense. ${ }^{198}$ We conclude that ASIC could (and should) have done more to mitigate

195 ASIC, 'Westpac Pays \$1 Million Following ASIC's Concerns About Credit Card Limit Increase Practices' (Media Release, 16-009MR, 20 January 2016) <http:/ /asic.gov.au/aboutasic/media-centre/find-a-media-release/2016-releases/16-009mr-westpac-pays-1-millionfollowing-asics-concerns-about-credit-card-limit-increase-practices/ $>$; ASIC, 'ASIC Commences Civil Penalty Proceedings Against Westpac for Breaching Home-loan Responsible Lending Laws' (Media Release, 17-048MR, 1 March 2017) <http://asic.gov.au/about-asic/media-centre/find-a-media-release/2017-releases/17048mr-asic-commences-civil-penalty-proceedings-against-westpac-for-breaching-homeloan-responsible-lending-laws/>. One of ASIC's stated concerns in the action against Westpac was the bank's lack of regard for the impact on borrowers of higher payments after the interest only period.

196 Julia Corderoy,'APRA, Basel Committee: Another GFC is Coming' Australian Broker (online) 6 April $2016<$ <ttp://www.brokernews.com.au/news/breaking-news/apra-baselcommittee-another-gfc-is-coming-214105.aspx>. Cohen, the Secretary-General of the Basel Committee that sets the international prudential standards for banks, describes the likelihood of future financial crises as statistically certain. Others also indicate that it is a matter of when and not if, future financial crises will occur: see, eg, World Economic Forum, Insight Report: The Global Risks Report 2017 (2017) 4 < http://reports.weforum.org/global-risks2017/preface/>, where Klaus Schwab, Founder and Executive Chairman of the World Economic Forum, suggests 'continued slow growth combined with high debt and demographic change creates an environment that favours financial crises and growing inequality'

197 See North, 'The Australian House Party has been Glorious - But the Hangover May Be Severe', above n 3, 83-92.

198 As Jane Diplock suggested in the wake of the global financial crisis, when 'everybody is making money, and there's exuberance in the markets, it's extremely difficult to be the 
present and prospective harm to Australian households resulting from elevated levels of indebtedness. Monitoring and enforcement of the responsible lending standards by ASIC should have been more systematic and regular during the present credit cycle, with especially strong supervision at the beginning of the cycle to ensure prudent lending standards were suitably established and maintained. However, the many other participants who have contributed to the credit boom could and should also have done more, including the lenders, borrowers, APRA, the Reserve Bank of Australia, and policy makers. ${ }^{19}$

We expect to see continued regulatory actions and other forms of litigation around responsible lending rules, especially when the external environment deteriorates and or the levels of financial stress and loan defaults rise significantly. ASIC and users of credit have powers under the NCCP to challenge the suitability and affordability of loans that have been issued and can seek compensation. Borrowers can also apply to the courts to have existing loan contracts revised or set aside under the NCC. These responsible lending provisions within the NCCP and NCC are likely to be used extensively to challenge the validity of existing loans in coming decades. To mitigate recurring issues for lenders and borrowers, we propose reforms to the responsible lending regimes that require credit providers to provide online warnings and sensitivity calculators on their websites and engage with borrowers about the risks involved. Consumers need to better comprehend, and be reminded of, the risks of taking on excessive amounts of debt and the criticality of maintaining financial buffers for adverse contingencies.

Jeremiah saying: 'Look, that's a cliff you're about to run over'. Nobody wants to hear that message, least of all [those] ... whose funds are perhaps being swollen by the very people making all this money.' ASIC, ASIC Summer School 2010, Securities and Investment Regulation: Beyond the Crisis (1-3 March 2010, Melbourne, Australia) 76.

199 As indicated in the introduction of this article, the roles and legal mandates of ASIC and APRA vary markedly, so the actions taken by APRA around lending standards will be reviewed in a companion article. 